\title{
HURRICANE WAVE STATISTICS FOR THE GULF OF MEXICO
}

\author{
Basil W. Wilson \\ Associate Professor, Department of Oceanography and Meteorology ${ }^{*}$ \\ Texas A.\& M. College, College Station, Texas.
}

\begin{abstract}
This paper contains the results of a statistical hindcast study of the heights and periods of significant waves generated by hurricanes in the Gulf of Mexico in the period 1900 to 1949. Results are presented in a series of polar plots of frequencies of occurrence of waves of given height and period at deep-water (100 fathoms depth) stations at different bearings offshore from five coastal stations (Brownsville, Tex., Gilchrist, Tex., Burrwood, Miss., Apalachicola, Fla., Tampa, Fla.).

Analysis was conducted by selecting a sample of 9 hurricanes and hindcasting by graphical moving fetch techniques, wave heights, periods and arrival times along eleven approach-directions to the five coastal stations for one storm, and from two to three approach directions for the remaining eight storms. Maximum heights and periods were correlated with hurricane characteristics (pressure, radius of maximum winds, forward velocity and direction). From the correlation the sample was increased by an additional 23 hurricanes whose characteristics were known. Heights and periods plottec against frequencies of occurrence gave mainly normal probability distributio Finally taking account of the total number of tropical storms occurring in the Gulf of Mexico in 50 years and the incidences of waves from various directio at the five stations, the chances of occurrence of full hurricane waves were evaluated.
\end{abstract}

\section{INTRODUCTION}

As part of a general statistical study of ocean wave heights and periods covering a period of three years at stations off the United States coast of the Gulf of Mexico, a separate analysis was undertaken of the wave conditions arising from a selection of the more severe hurricanes occurring in the Gull in the first half of the present century. The method used in hindcasting the waves was specially developed to handle the intricacies of a moving fetch an variable wind [Wilson, 1955].

*

Contribution from the Department of Oceanography and Meteorology, Agricultural and Mechanical College of Texas, Oceanography and Meteorology Series No. 100. 


\section{HURRICANE WAVE STATISTICS FOR THE GULF OF MEXICO}

In the 44 years from 1900 to 1943 Taniehill [1944] records a total of some 112 tropical storms as having invaded the Gulf of Mexico. Of these only 66 comply with the criterion of a central pressure less than 29.00 ins., qualifying them for consideration as full hurricanes [Myers, 1954]. From a group of 34 of these, listed by Myers, a selection was made of 10 of the most severe ones for purposes of detalled study.

\section{SELECTION OF HURRICANES FOR HINDCAST STUDY}

The choice of hurricanes was based primarily on their potential for generating storm waves, without regard to capacity for raising storm tides. The criterion used was the magnitude of 'wave energy index', E, [Reid, 1955] defined as

$$
E=(\Delta p) R
$$

where $\mathrm{R}$ is the radial distance from the hurricane center at which maximum winds are encountered and $\Delta p$ is the anomaly of pressure from normal at the storm center; that is

$$
\Delta \mathrm{p}=\mathrm{p}_{\mathrm{n}}-\mathrm{p}_{\mathrm{o}}
$$

$\mathrm{p}_{\mathfrak{n}}$ being normal pressure at a large distance from the hurricane eye and $\mathrm{p}_{\mathrm{o}}$ the minimum central pressure. Values of $\mathrm{R}, \mathrm{p}_{\mathrm{n}}, \mathrm{p}_{\mathrm{o}}, \Delta \mathrm{p}$, and $\mathrm{E}$ for the selected hurricanes are given in Table I.

Table I: Characteristics of Selected Gulf of Mexico Hurricanes

\begin{tabular}{l|l|c|c|c|c|l}
\hline Date & \multicolumn{1}{|c|}{ Place } & $\begin{array}{c}\mathrm{p}_{\mathrm{n}} \\
\text { 1ns. } \\
\text { merc.) }\end{array}$ & $\begin{array}{c}\mathrm{p}_{\mathrm{O}} \\
\text { (ns. } \\
\text { merc.) }\end{array}$ & $\begin{array}{c}\Delta \mathrm{p} \\
\text { (1ns. } \\
\text { merc.) }\end{array}$ & $\begin{array}{c}\mathrm{R} \\
\text { (naut. } \\
\text { m1.) }\end{array}$ & $\begin{array}{l}\mathrm{E} \\
\text { (n.mi. } \\
\text { 1ns.) }\end{array}$ \\
\hline Sept. 8,1900 & Galveston, Tex. & 29.78 & 27.64 & 2.14 & 14 & 30.0 \\
Aug. 16,1915 & Velasco, Tex. & 29.57 & 28.14 & 1.43 & 32 & 45.8 \\
Sept. 29,1915 & New Orleans, La. & 30.14 & 27.87 & 2.27 & 29 & 65.8 \\
Aug. 18,1916 & Santa Gertrud1s,Tex & 30.77 & 28.00 & 2.77 & 35 & 96.9 \\
Sept. 9,1919 & Dry Tortugas, Fla. & 29.73 & 27.44 & 2.29 & 15 & 34.3 \\
Sept.14,1919 & Corpus Christi, Tex & 29.54 & 28.65 & 0.89 & 75 & 66.8 \\
June 22,1921 & Houston, Tex. & 30.03 & 28.38 & 1.65 & 17 & 28.0 \\
Aug. 13,1932 & E. Columb1a, Tex. & 30.11 & 27.83 & 2.28 & 12 & 27.4 \\
Sept. 5,1933 & Brownsville, Tex. & 30.24 & 28.02 & 2.22 & 30 & 66.6 \\
Sept.17,1947 & Hillsboro, Fla. & 29.83 & 27.76 & 1.09 & 19 & 20.7 \\
Sept.19,1947 & New Orleans, La. & 29.70 & 28.61 & 1.06 & 28 & 29.7
\end{tabular}

Choice of the above hurricanes was also conditioned by their tracks across the Gulf, shown in Fig. 1. Other hurricanes returning larger E values were ruled out because their paths were generally unfavorable to development of onshore waves. The hurricane of August 1916 had ultimately to be discarded because of a lack of adequate synoptic data near its center. 


\section{STATION POINTS AND APPROACH DIRECTIONS}

Wave hindcasts were undertaken along particular approach directions to five coastal stations along the United States shores of the Gulf of Mexico. These station points and the approach directions are illustrated in Fig. 2(a) and are defined in Table II below.

Table II : Locations of Reference Wave Stations

\begin{tabular}{|c|c|c|c|}
\hline Station Symbol & Latitude & Longitude & Vicinity \\
\hline A & $25^{\circ} 55^{\prime} \mathrm{N}$ & $97^{\circ} 09^{\prime} \mathrm{W}$ & Brownsville, Texas \\
\hline B & $29^{\circ} 30^{\prime} \mathrm{N}$ & $94^{\circ} 30^{\prime} \mathrm{W}$ & Gilchrist (near Galveston) Texas \\
\hline C & $29^{\circ} 03^{\prime} \mathrm{N}$ & $89^{\circ} 20^{\prime} \mathrm{W}$ & Burrwood (southwest pass), Miss \\
\hline $\mathrm{D}$ & $29^{\circ} 35^{\prime} \mathrm{N}$ & $85^{\circ} 00^{\prime} \mathrm{W}$ & Apalachicola, Florıda \\
\hline $\mathrm{E}$ & $27^{\circ} 55^{\prime} \mathrm{N}$ & $82^{\circ} 51^{\prime} \mathrm{W}$ & Tampa, Florida \\
\hline
\end{tabular}

In the results that will be quoted hereafter the deep-water offshore stations referred to will be those points marking intersections of the 100 fathoms der contour with the various approach directions. These station points are defin more specifically in Table III hereunder:

Table III: Locations of Deep-Water Offshore Wave Stations

\begin{tabular}{c|c|l|l|c}
\hline \multirow{2}{*}{ Station } & \multirow{2}{*}{$\begin{array}{c}\text { Approach } \\
\text { Direction }\end{array}$} & \multirow{2}{*}{ Bearing } & \multicolumn{2}{|c}{ Location at 100 fathom depth } \\
\cline { 3 - 5 } & & Latitude & Longitude \\
\hline \multirow{2}{*}{$\mathrm{A}$} & $\mathrm{AA}_{1}$ & $\mathrm{SE}$ & $25^{\circ} 21^{\prime} \mathrm{N}$ & $96^{\circ} 26^{\prime} \mathrm{W}$ \\
& $\mathrm{AA}_{2}$ & $\mathrm{E}$ & $26^{\circ} 00^{\prime} \mathrm{N}$ & $96^{\circ} 19^{\prime} \mathrm{W}$ \\
& $\mathrm{BB}_{1}$ & $\mathrm{~S}$ & $27^{\circ} 51^{\prime} \mathrm{N}$ & $94^{\circ} 27^{\prime} \mathrm{W}$ \\
$\mathrm{C}$ & $\mathrm{BB}_{2}$ & $\mathrm{SE}$ & $27^{\circ} 57^{\prime} \mathrm{N}$ & $92^{\circ} 41^{\prime} \mathrm{W}$ \\
& $\mathrm{CC}_{1}$ & $\mathrm{SW}$ & $28^{\circ} 37^{\prime} \mathrm{N}$ & $89^{\circ} 47^{\prime} \mathrm{W}$ \\
& $\mathrm{CC}_{2}$ & $\mathrm{~S}$ & $28^{\circ} 39^{\prime} \mathrm{N}$ & $89^{\circ} 20^{\prime} \mathrm{W}$ \\
$\mathrm{D}$ & $\mathrm{CC}_{3}$ & $\mathrm{SE}$ & $28^{\circ} 48^{\prime} \mathrm{N}$ & $89^{\circ} 07^{\prime} \mathrm{W}$ \\
& $\mathrm{DD}_{1}$ & $\mathrm{SW}$ & $29^{\circ} 03^{\prime} \mathrm{N}$ & $85^{\circ} 53^{\prime} \mathrm{W}$ \\
$\mathrm{E}$ & $\mathrm{DD}_{2}$ & $\mathrm{~S}$ & $28^{\circ} 10^{\prime} \mathrm{N}$ & $84^{\circ} 49^{\prime} \mathrm{W}$ \\
& $\mathrm{EE}_{1}$ & $\mathrm{~W}$ & $27^{\circ} 45^{\prime} \mathrm{N}$ & $85^{\circ} 11^{\prime} \mathrm{W}$ \\
& $\mathrm{EE}_{2}$ & $\mathrm{SW}$ & $26^{\circ} 21^{\prime} \mathrm{N}$ & $84^{\circ} 23^{\prime} \mathrm{W}$ \\
\hline
\end{tabular}




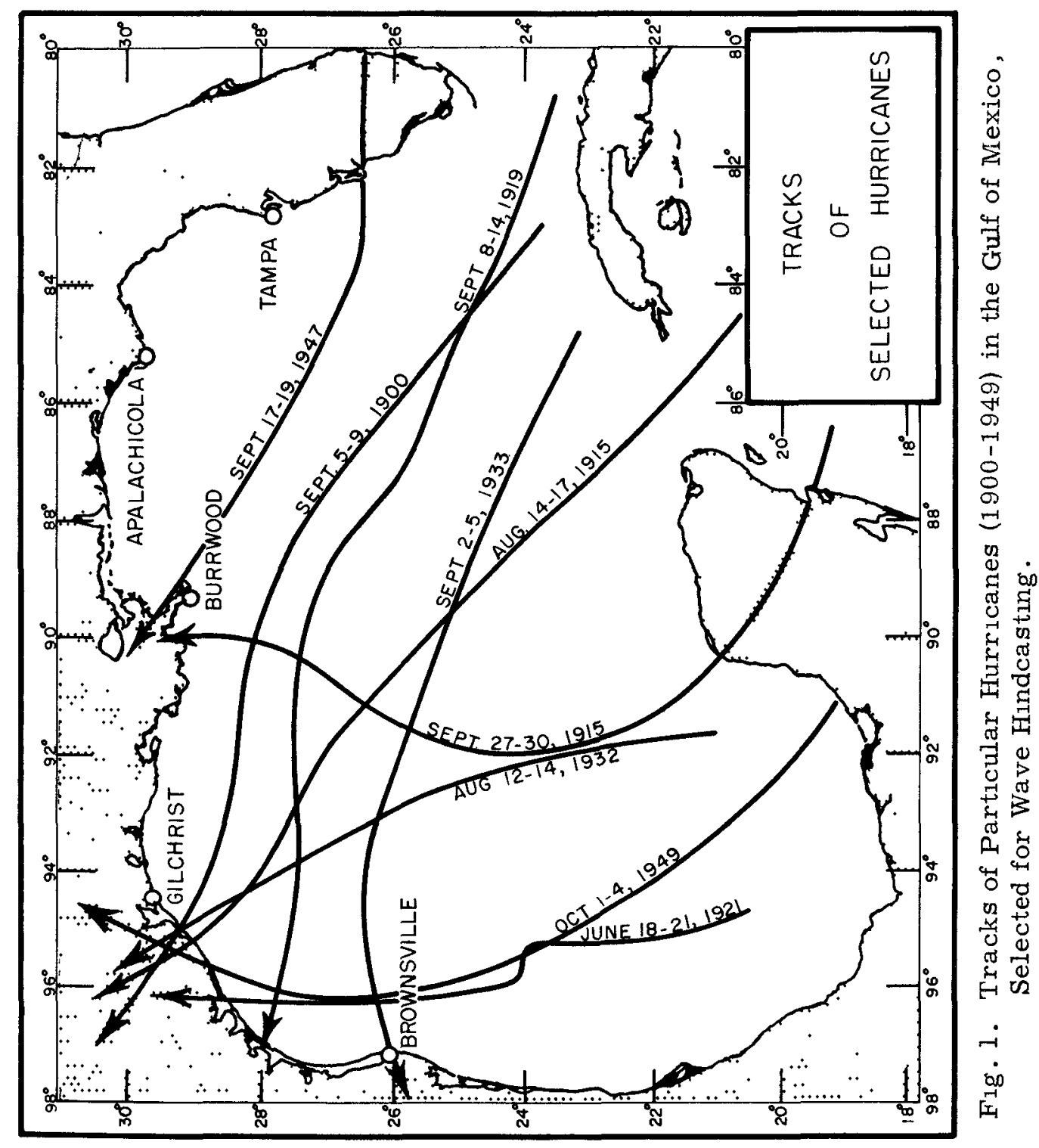




\section{COASTAL ENGINEERING}

\section{PREPARATION OF SYNOPTIC WEATHER MAPS}

The graphical wave forecastıng procedure for moving varıable-wind fetches [Wilson, 1955] is dependent upon preparation of adequate space-time wind-fields delineating wind strengths along the lines of approach of the wavt to the different stations. To obtain these it was necessary to estimate surfar wind velocities over the entire Gulf area prevailing during the different synoptic weather situations. The rough reticulation system shown in Fig. 2(a was adopted to assist this procedure, the circled points of the grid network being selected as locations for determining wind speeds.

Synoptic weather data were obtained from the daily historical weather maps of the Weather Bureau. * In general the isobar contours at $5 \mathrm{mb}$ interv given on these maps were rather poor fits to the observational data from she stations and ships and it was found necessary to re-draw the maps entirely: insert additional contours at $1 \mathrm{mb}$ intervals. In addition it was considered necessary to interpolate intermediate 12-hourly maps to give an adequate pi ture of the time changes in the wind. Typical examples of the isobaric chart constructed on this basis, for the case of the Galveston hurricane of Septem 5-9, 1900, are shown in Figs. 3 and 4.

Found to be generally representative of all the hurricanes studied was an ellipticity of isobars round the storm centers revealing lesser pressure gradients on the left hand sides than on the right in the direction of motion. Having regard to the nature of the data, reasonable accord was found betwet observed wind directions and those indicated by the isobars.

The pressure patterns were used exclusively to determine surface wir velocities, and observational data from ships and shore stations were used merely as checks and controls for minor modification when necessary. No attempt was made to define isobars for pressures below about $995 \mathrm{mb}$ near the hurricane centers; lack of information in these areas militated against $t$

\section{DETERMINATION OF HURRICANE CHARACTERISTICS OVER THE OCE}

A formula for the rate of change of pressure, $p$ with radial distance 3 from a hurricane center has been evolved by the Hydrometeorological Sectic of the Weather Bureau (HMS/WB) from studies made of various hurricanes : the times of their crossing of a coastline [Myers, 1954], namely

$$
\frac{d p}{d r}=(\Delta p) \frac{R}{r^{2}} e^{-R / r}
$$

* The Weather Bureau (Office of Climatology) was unable to supply more $d \varepsilon$ at the time this study was in progress. 


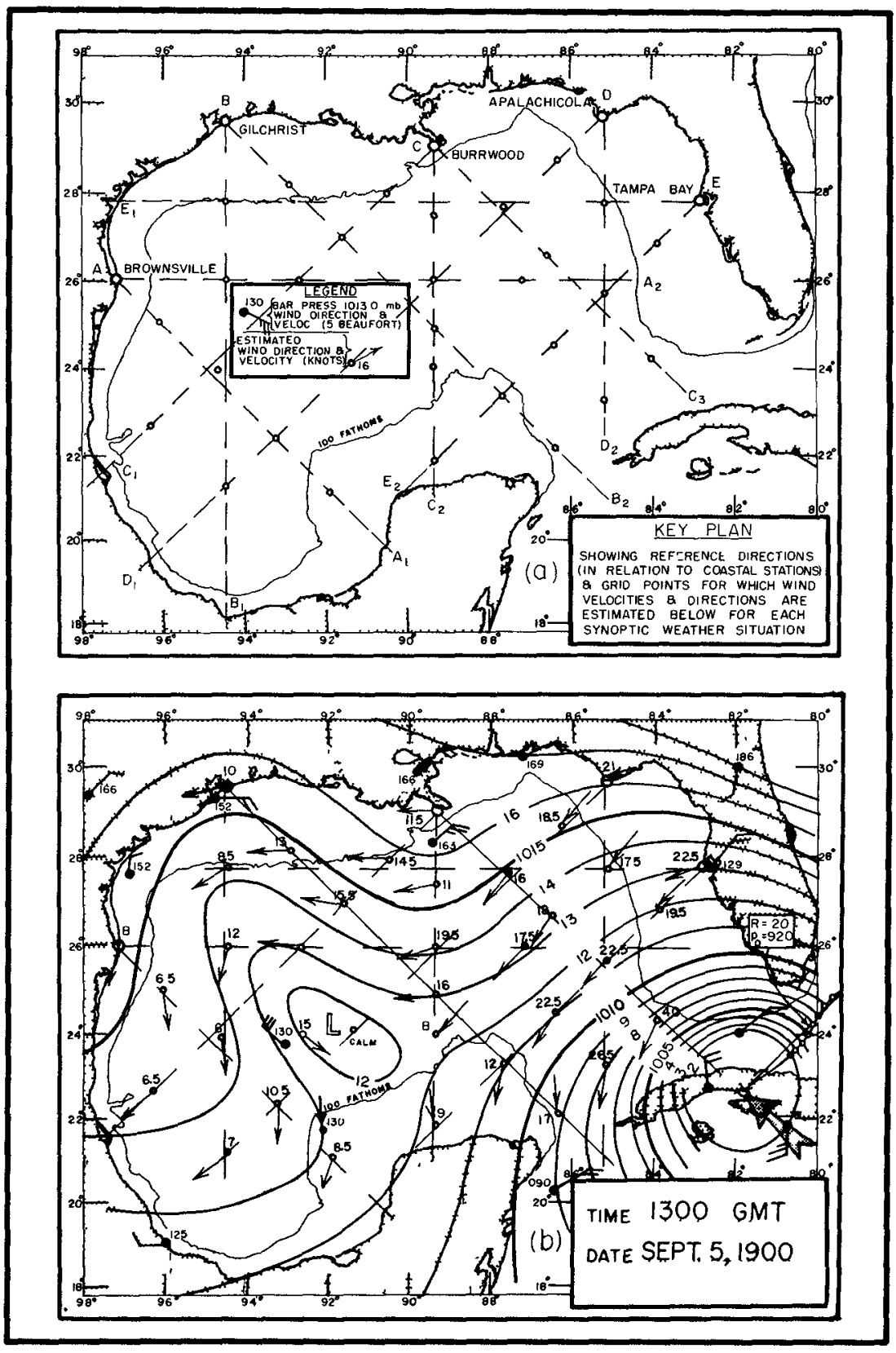

Fig. 2. (a) Key Diagram of Reference Stations, Approach Directions, Reticulation System and Codes for Synoptic Niaps of the Gulf of Mexico.

(b) Synoptic Map of Gulf of Mexico Defining Entrance to the Gulf of the Hurricane of Sept. 5-9, 1900. 


\section{COASTAL ENGINEERING}

As in Eq.(1), the principal characteristics of a hurricane here are 1ts parameters $R$ and $\Delta \mathrm{p}$. A natural question immediately arising is whether $R$ and $\Delta p$ are sensibly variable during the life history of a hurricane after the latter has acquired its so-called ' maturity' . It seemed implicit in the synoptic maps that changes from intensification and mitigation were proceeding continuously in all the storms during their progression. This was borne out also by the different values of $R$ and $\Delta p$ computed by HMS/WB for those hurricanes which made two land crossings (eg, 1919 and 1947 hurricanes, Table I).

The initial problem posed then was to evaluate $R$ and $\Delta p$ for a hurricane during its transit over water. Upon these quantities depended the magnitudes of the important winds near the hurricane centers.

Profiles of pressure through the storm centers in the direction of motio at different times were plotted, as in Fig. 5(a), from information in the synopti maps. The supposition then made was that, if these profiles obeyed the law o the integrated Eq. (3)

$$
\mathrm{p}=\mathrm{p}_{\mathrm{o}}+\left(\mathrm{p}_{\mathrm{n}}-\mathrm{p}_{\mathrm{o}}\right) \mathrm{e}^{-\mathrm{R} / \mathrm{r}},
$$

the unknown elements $p_{o}$ and $R$ at any given time could be evaluated by maki the equation fit two points on each profile, $\left(p_{1}, r_{1}\right)$ and $\left(p_{2}, r_{2}\right)$. Fig. 5(b) 1llustrates the graphical method used in solving the two simultaneous equatio obtained in this procedure. On trial it was found that $p_{o}$ values thus derived were much too high to be valid and it was obvious therefore that the actual pressure profiles were not conforming adequately to the theoretical pattern 0 Eq.(4).

The final attack on this problem was made by use of a series of auxilia polar 'spiral' diagrams such as $F_{1 g} .6$ giving for a specific value of $p_{0}$ ( $900 \mathrm{mb}$ in this example) and a $p_{n}$ value of $1020 \mathrm{mb}$, spiral isobars of pressi $\mathrm{p}$ applicable to different radial-line values of $\mathrm{R}$. These diagrams were computed from Eq.(4) and drawn to the same scale as the synoptic maps of the Gulf (Figs. 1 and 2) so as to be superimposable on the pressure pattern of the hurricane in the plan sense.

The spiral diagrams afforded a trial and error method of finding some radial direction in the storm along which the pressure distribution would accord most satisfactorily with Eq.(4). To achieve the optımum agreement, a particular spiral diagram (such as for $p_{o}=910 \mathrm{mb}$ ) would be overla1d on a synoptic map so that its center coincided with the apparent hurricane center at the time considered (Fig. 7). The diagram would then be rotated about th center until the intersections between the isobars on the two charts most nearly lined up in a radial direction as shown in Fig. 7. 


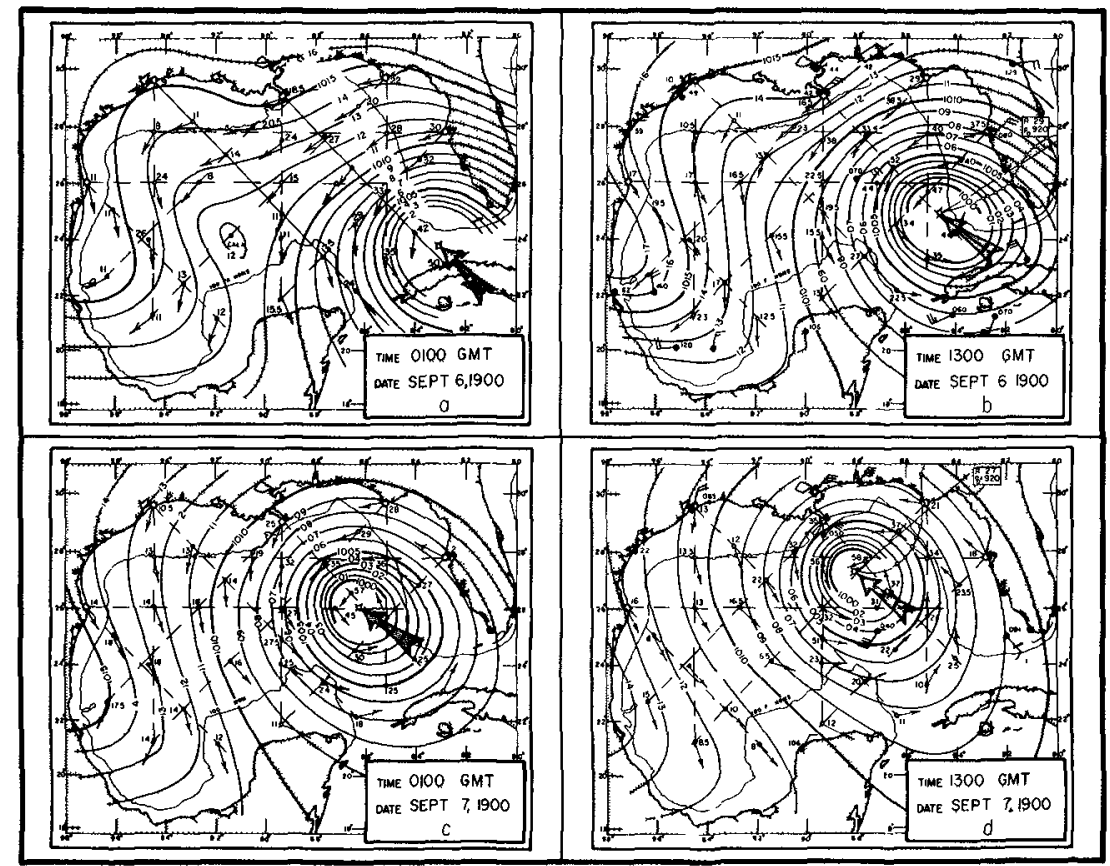

Fig. 3. 12-Hourly Synoptic Maps for Gulf of Mexico. (a-d) Hurricane of Sept. 6-7, 1900.

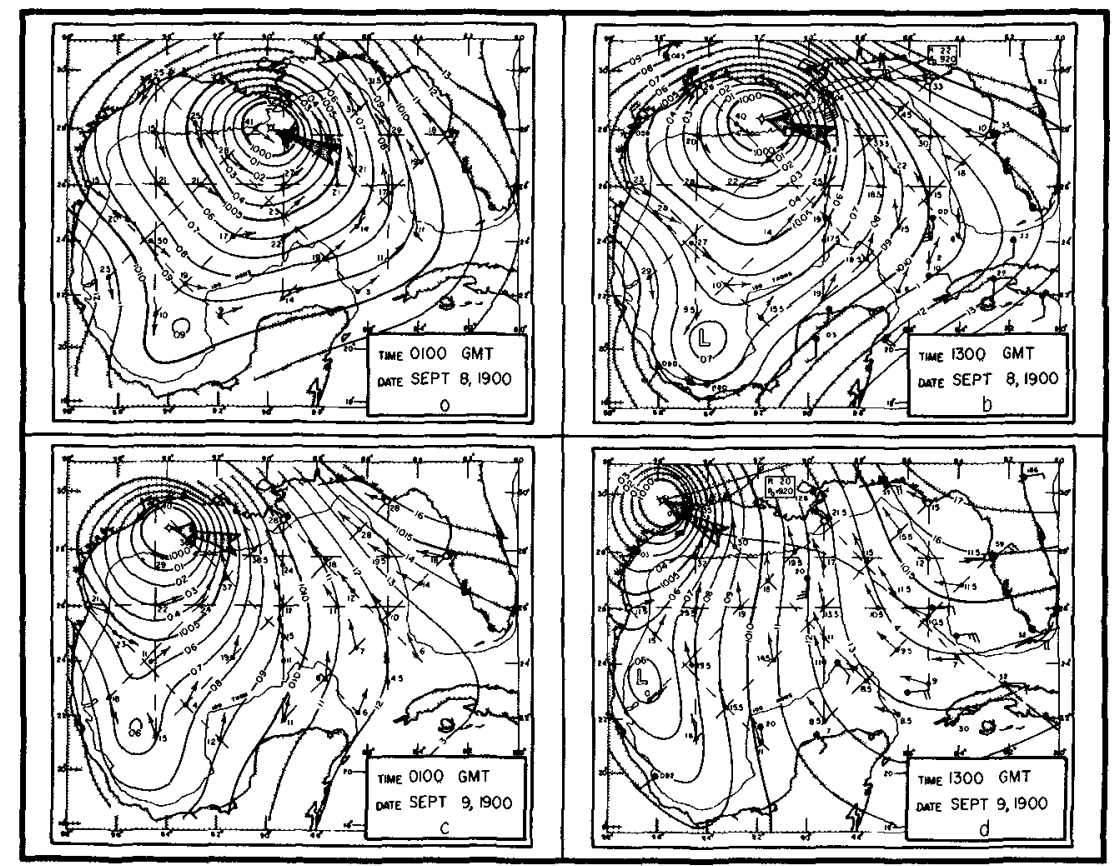

Fig. 4. 12-Hourly Synoptic Maps for Gulf of Mexico. (a-d) Hurricane of Sept. 8-9, 1900. 


\section{COASTAL ENGINEERING}
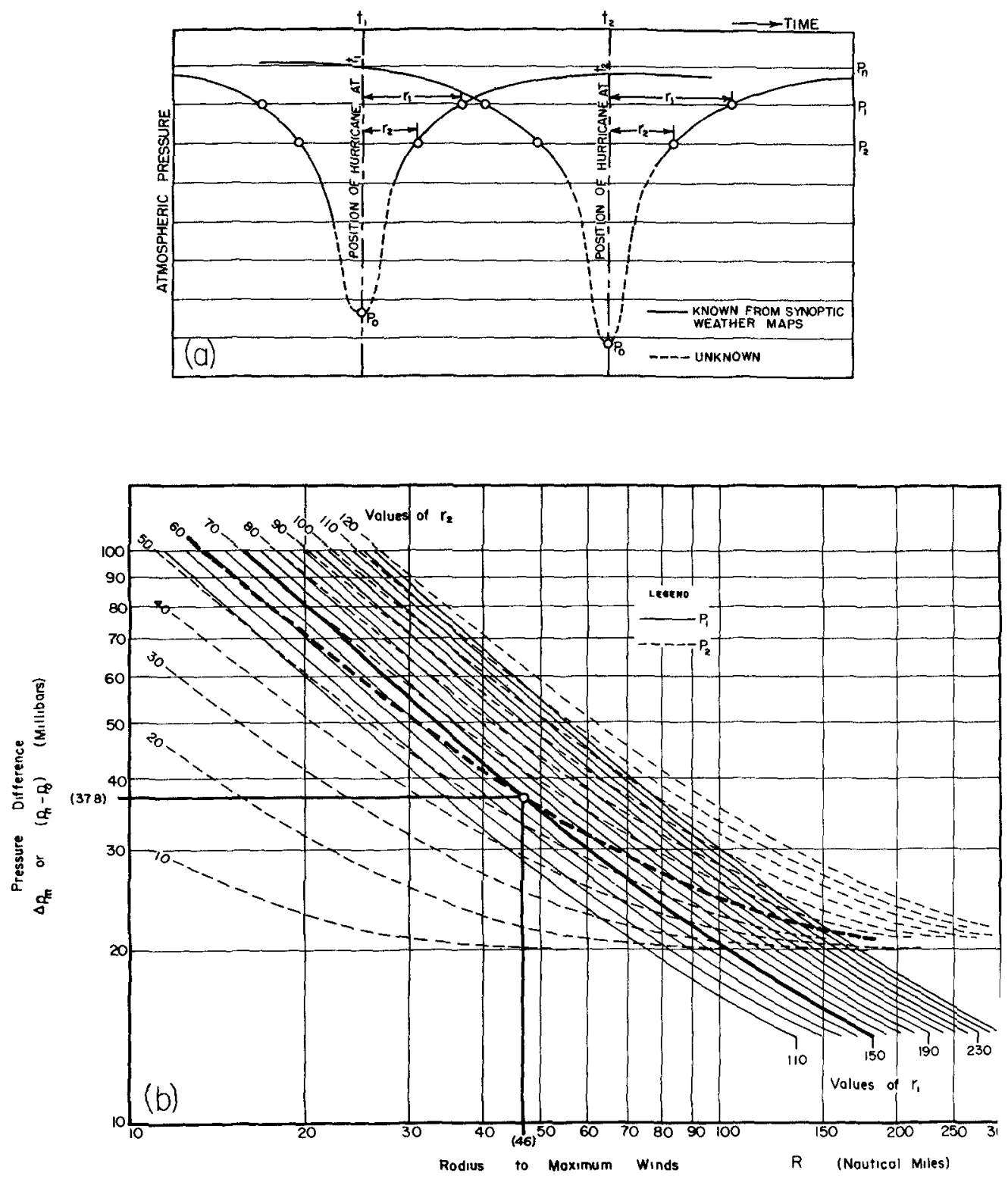

Fig. 5. (a) Schematic Diagram of Pressure Profiles of Hurricane at Different Times along Travel Path. (b) Example of Graphic: Solution of Two Simultaneous Equations in $\Delta p$ and $R$. [ Frc pressure profile (e.g., Fig. 5 (a) ) $\mathrm{p}_{1}=1005 \mathrm{mb}, \mathrm{r}_{1}=150$ $\mathrm{mi} ., \mathrm{p}_{2}=995 \mathrm{mb} ; \mathrm{r}_{2}=60 \mathrm{n} . \mathrm{m1}$., whence solution $\Delta \mathrm{p}=37 . i$ and $R=46 \mathrm{n} . \mathrm{mi} \cdot]$ 


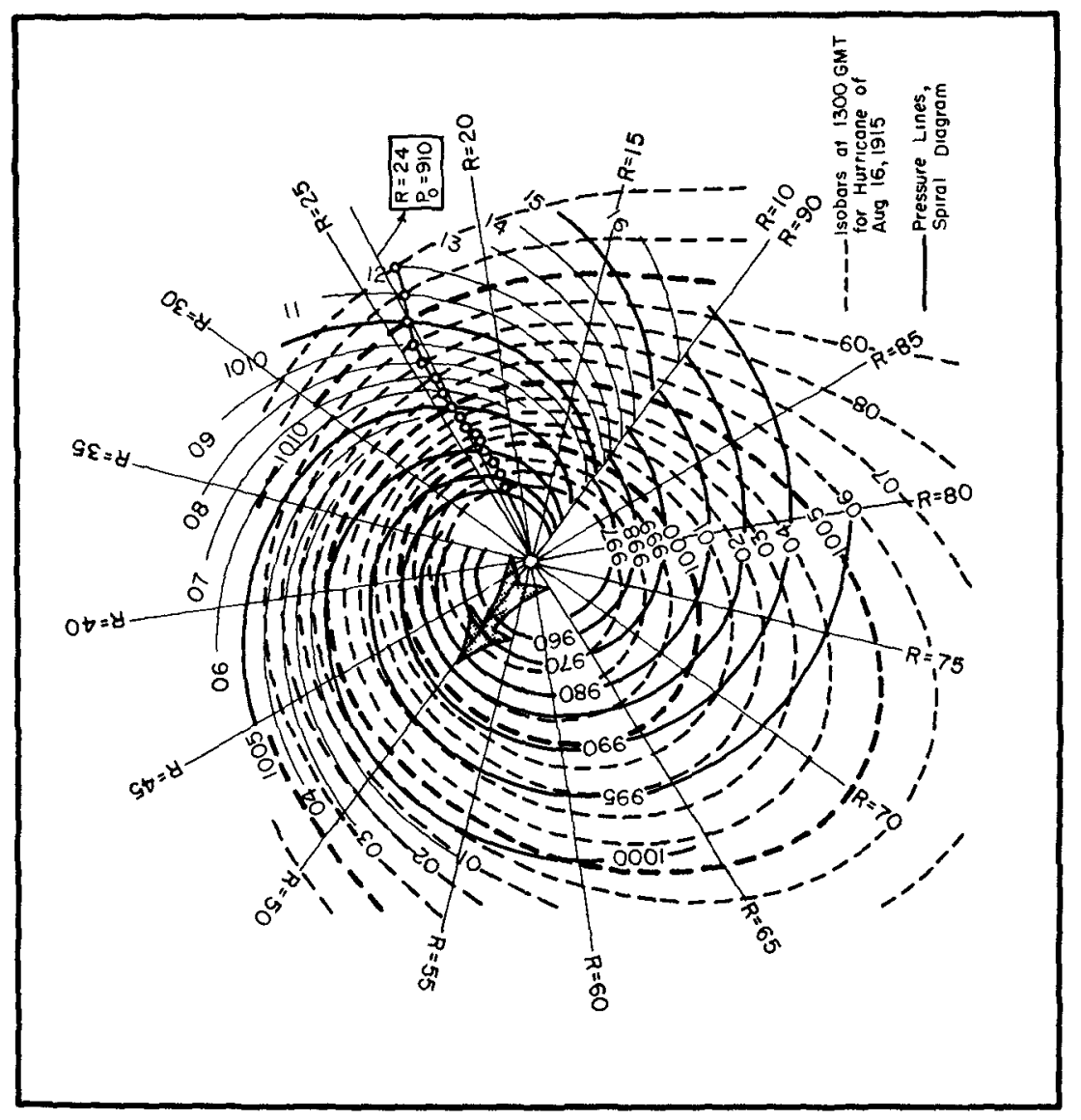

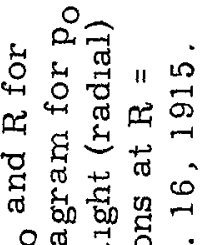

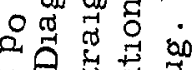

出吉苛焉

둔

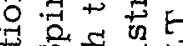

की

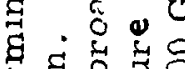

द

\& 0 \%

幽

$\rightarrow$ on 2

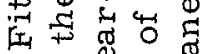

ts \& $\&$ o

on 0 记

D०० 0

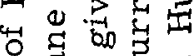

0. 윰

를 द्व

द्वृ

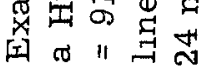
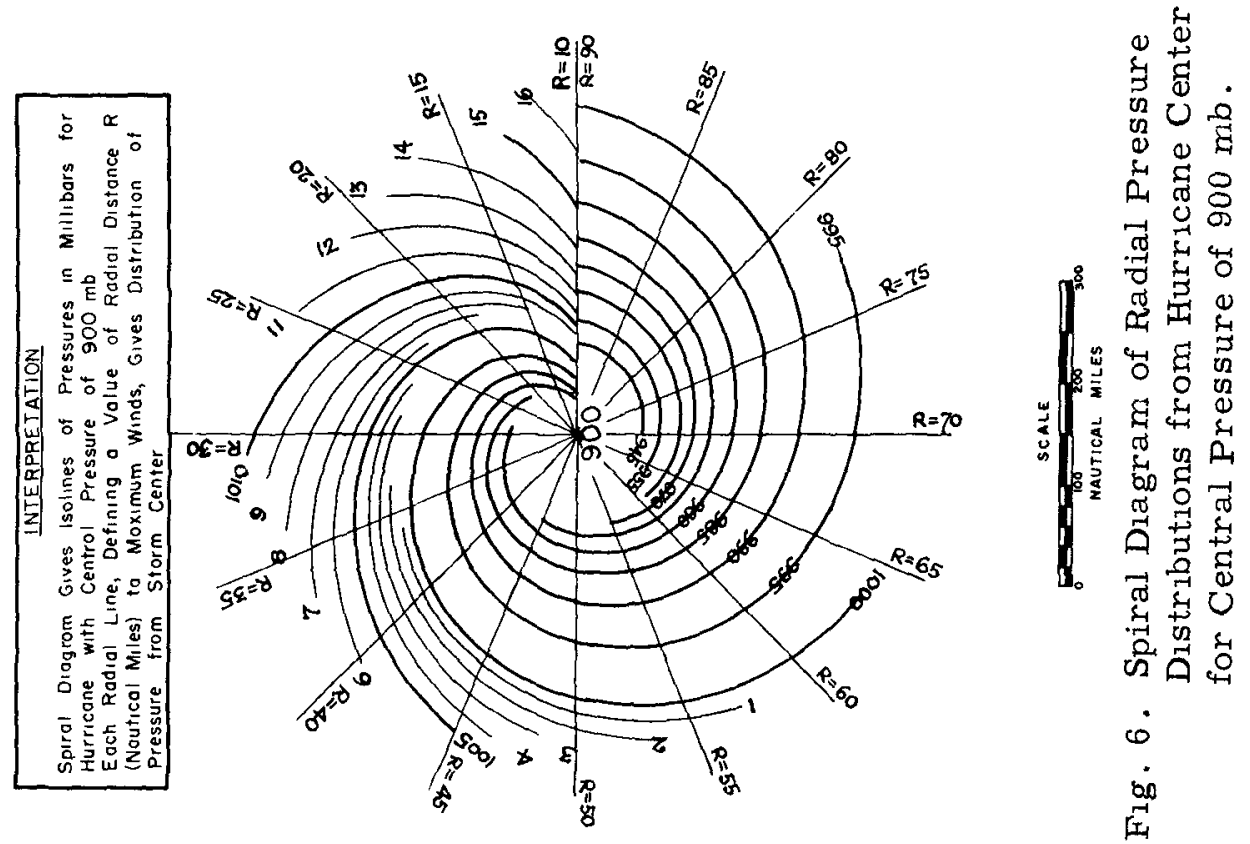


\section{COASTAL ENGINEERING}

It was found that by applying several spiral diagrams to each map a condition of best fit could usually be found, permitting definition of central pressi $\mathrm{p}_{\mathrm{o}}$ and radius, $R$, to maximum winds. In almost all the storms thus treated reasonable agreement between the actual pressure distribution and the theoret ical could be established only on the right hand sides in the direction of travel Values of $\mathrm{p}_{\mathrm{o}}$ and $\mathrm{R}$ found in this way appeared rational and in reasonable accord with the values cited by HMS/WB in Table 1. Plotted as functions of time as in Fig. 8, some idea was avallable of the continuous changes taking place in a hurricane along its path at sea.

\section{DETERMINATION OF SURFACE WIND VELOCITIES OVER THE OCEAN}

Surface wind velocities at the various points of the reticulation system shown in Fig. 2(a) were obtained from the pressure patterns (eg. Fig. 2) by various graphical alds devised from the fundamental equation of cyclonic gradient flow in a moving cyclone. This, according to Holmboe [1945], is :

$$
K_{h s} U^{2}+\left(2 \Omega \sin \emptyset+\frac{\partial \psi}{\partial t}\right) U-\frac{1}{\rho} \frac{\partial p}{\partial r}=0
$$

where $K_{h s}$ is the horizontal curvature of the streamlines in a circular cyclor streamline pattern, $U$ the horizontal wind velocity above the friction layer, $S$ the angular velocity of the earth, $\varnothing$ the latitude of the point considered, $\psi$ tl horizontal angle of wind vector, positive counterclockwise from some fixed reference such as the west-east direction, $\rho$ the density of the air, $p$ the pr sure and $r$ the radius from the center to the point considered.

For a hurricane moving with velocity V, Eq.(5) reduces to

$$
\frac{U^{2}}{r}+\frac{U V}{r} \sin \theta+2 \Omega U \sin \emptyset=\frac{1}{\rho} \frac{\partial p}{\partial r}
$$

where $\theta$ now defines the angle of bearing at the center of the point considerer positive counterclockwise with reference to the direction of travel of the stor equation

For large $r$ the solution of Eq.(6) approximates the geostrophic wind

$$
\mathrm{U}=\mathrm{U}_{\mathrm{g}}=\frac{\frac{1}{\rho} \frac{\partial \mathrm{p}}{\partial \mathrm{r}}}{2 \sin \emptyset}
$$

but near the storm center the full Eq.(6) is involved and its solution for $U \mathrm{~m}$ be designated the gradient wind $U_{G}$. It is possible to resolve this solution $f$ $\mathrm{U}_{\mathrm{G}}$ in the form:

$$
\mathrm{U}_{\mathrm{G}}=\mathrm{U}_{\mathrm{c}}\left[\sqrt{\boldsymbol{\gamma}^{2}+1}-\boldsymbol{\gamma}\right]
$$




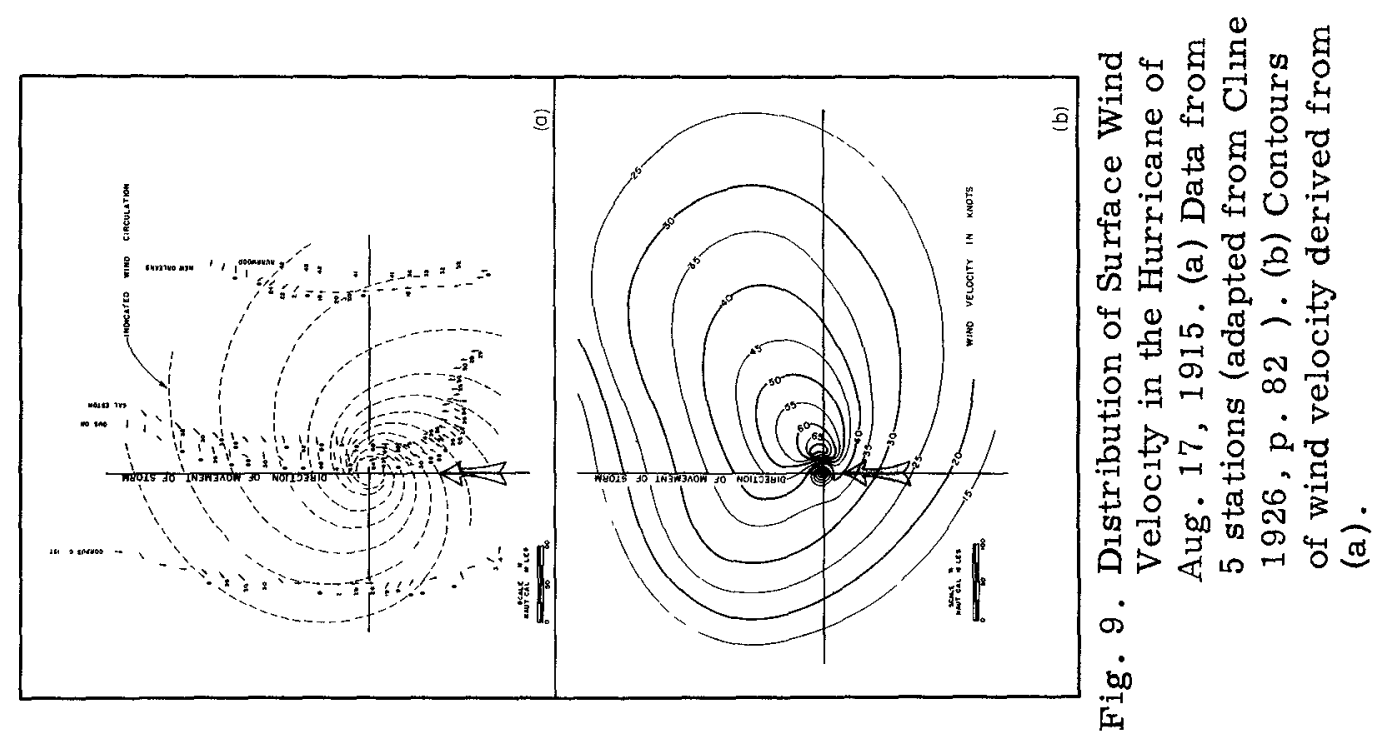

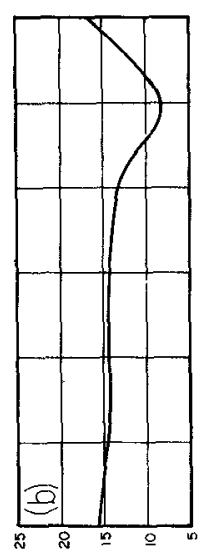

(stouy) $\wedge$ - moxdAnH to paads puotiobodosd

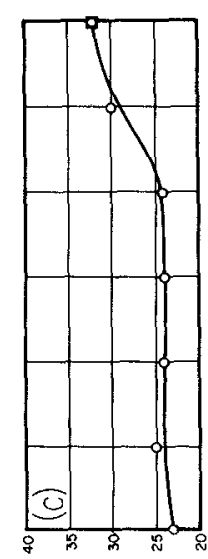

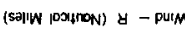
unwixow of snipoy

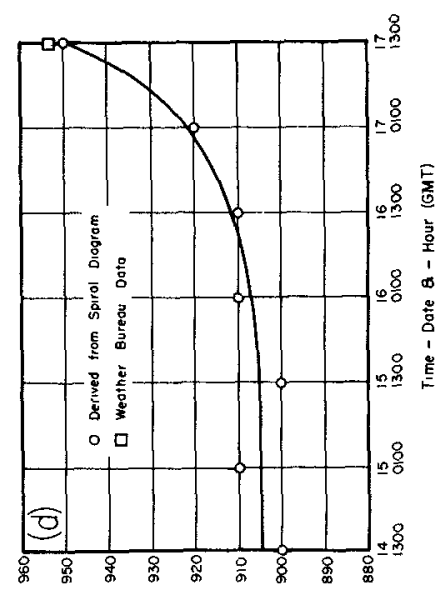

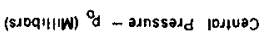

In

$\dot{y} \widehat{U}$

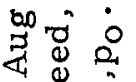

넝 은 운

䗎

矛兘

$\rightarrow \overbrace{0}$

至范焉

.

कूष

䓎

.

$\stackrel{0}{0}$

胥药

刃

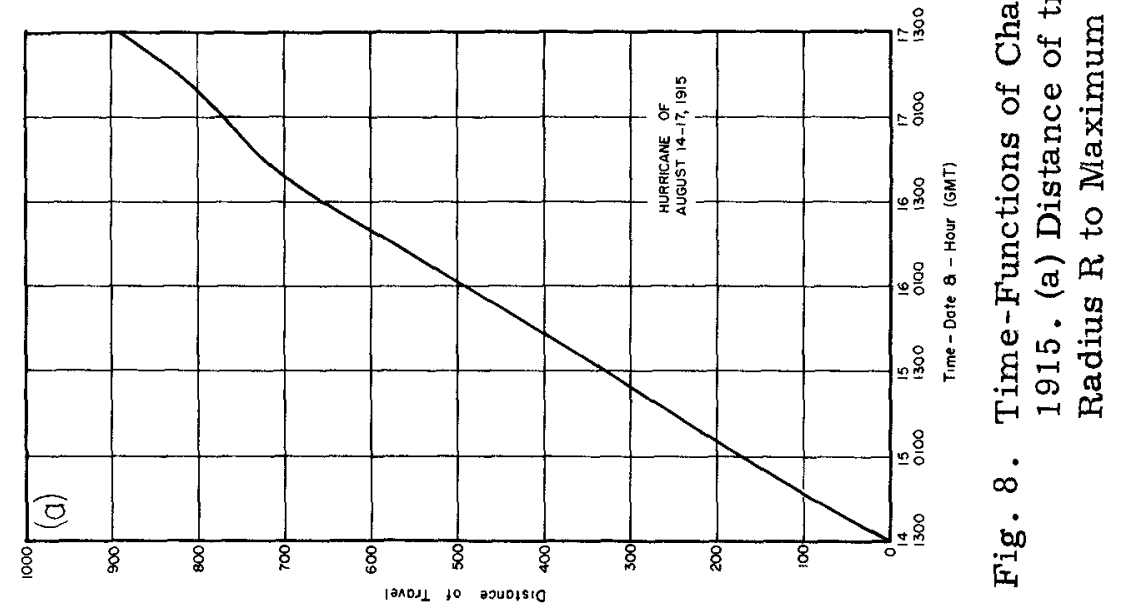




\section{COASTAL ENGINEERING}

where $U_{C}$, the cyclostrophic wind, is defined as

$$
\mathrm{U}_{\mathrm{c}}=\sqrt{\frac{\mathrm{r}}{\rho} \frac{\partial \mathrm{p}}{\partial \mathrm{r}}}
$$

and

$$
\gamma=\frac{1}{2}\left(\frac{\mathrm{V} \sin \theta}{\mathrm{U}_{\mathrm{c}}}+\frac{\mathrm{U}_{\mathrm{c}}}{\mathrm{U}_{\mathrm{g}}}\right)
$$

The problem of determining the surface winds was fraught with knowing the ratio of the surface wind, $U_{S}$, to the geostrophic or gradient wind (having regard to atmospheric stabllity), and the degree of inclination of the wind to the isobars. The assumption was made that sea-air temperature differences within the ambit of a Gulf hurricane would be small enough to be taken as zero Allowances for currvature in estımates of geostrophic wind, $U_{F}$, were made in amounts used in current wave forecasting practice [Beach Erosion Board, 195.

Since the whole system of estimating surface wind velocities from the 1sobars involves many approximations it was considered sufficient to insert wind directions on the maps with deflection angles in the ne1ghborhood of $18^{\circ}$ (based on formulae of Haurwitz [1941] and Holmboe [1945]) with some decreas on near approach to the hurricane centers as suggested by HMS/WB [Myers, 1954]. Allocated directions were modified here and there to accord with ship or shore observations.

For situations in which a hurricane was close to the coast it was possibl to make use of the wind records from several coastal stations in the vicinity according to the information and method given by Cline [1946] as illustrated in Fig. 9(a). Such data when contoured for wind velocity, as in Fig. 9(b),gave useful information on the distribution of wind magnitudes in a storm and serve as a boundary-check on the wind velocities evaluated from the 1sobars.

\section{CONSTRUCTION OF SPACE-TIME WIND-FIELDS}

Surface wind velocities, $U_{S}$, found for the different points of the gridnetwork, are shown in the sample Figs. 2 to 4. The resolved components of these along the direction lines toward the five coastal stations $A$ to $E$ were determined. A component directed toward the coast was taken as positive; negative, if directed away from the coast.

The task of compiling wind-fields [Wilson, 1955] for all 11 directions (Table III) for all 9 hurricanes (Table I) was beyond available resources. It was decided therefore to treat all directions for just one hurricane, that of Aug. 14-17, 1915, and select only two or three directions for each of the remaining 8 selected hurricanes. 
Fig. 10 is typical of space-time plots of wind velocity components (contoured at intervals of 2.5 knots) along the two directions for the hurricame of Aug. 14-17, 1915. Stippled areas define positive zones of wind directed shoreward, in contradistinction to offshore winds in negative (white) zones. A characteristic feature of these diagrams when the storm-track crosses a direction line (cf. Figs. 1 and 2) is a peak and trough formation flanking each other across a nodeline as shown in Fig. 10 (Burrwood). Fig. 10 (Gilchrist), on the otherhand, is typical of a condition in which the hurricane is travelling along or nearly parallel to the approach-direction.

In compiling the wind-field at the peaks and troughs in the neighborhood of the crossing point of the storm over the direction line, it was found necessary to use an estimate of wind distribution such as Fig. 9(b) in order to obtain the magnitudes and positions in space and time of the maximum positive and negative wind components.

It cannot be gainsaid that the method of estimating surface wind velocities from gradient wind speeds is subject to appreciable error. However, by the very nature of the procedures involved in compiling the space-time wind-fields, these errors, which are likely to be both plus and minus, are subject to considerable smoothing from the act of contouring the diagrams and by the influence of adjacent observations upon each other.

\section{GRAPHICAL HINDCASTING OF WAVE CHARACTERISTICS AND ARRIVAL TIMES}

The graphical procedure of conducting a deep-water wave hindcast for a variable wind, moving fetch has been described elsewhere [Wilson, 1955] and therefore need not be repeated here. Starting points in the wind fields from which wave propagation lines were run graphically toward the deep-water limits (Table III) were chosen by judgement so as to give the largest possible end-result of significant wave height and period. In Fig. 10 (Gilchrist), for example, starting points are all located along what is virtually the line of advance of the hurricane center or the node-line, demarcating positive and negative wind zones, being so chosen as to give the longest possible wave propagation lines falling within the stippled (positive) zone and passing through the region of high wind velocities, near the right-hand corner of the wind-freld. The propagation lines from each starting point curve downward and to the right in Fig. 10. Also radıating from starting points are height lines $\mathrm{H}$ (upward and to the right) and period lines $T$ (downward and to the left). Where the propagation lines intersect the contour of 100 fathoms depth (dash-line), the heights and periods attained by waves in the available time and distance from their origin are indicated by figures. The wave arrival times, of course, are given by the time-ordinates of these intersection points. 


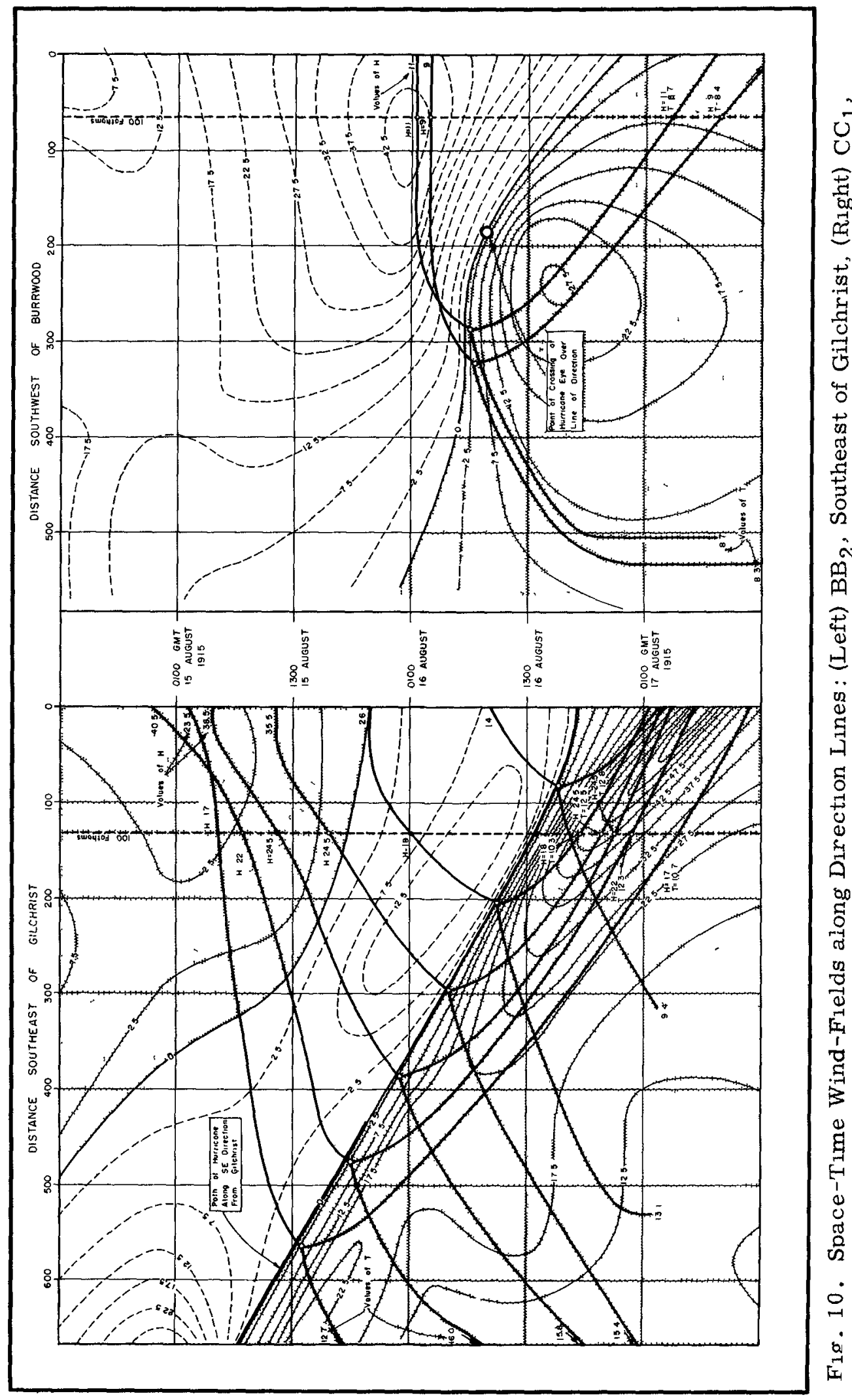




\section{HURRICANE WAVE STATISTICS FOR THE GULF OF MEXICO}

With certain wind-fields almost the entire area was negative, makıng inc1dence of onshore waves virtually 1 mpossible. In such cases no attempt was made to apply the graphical procedures.

Typical results from conducting the hindcasts are portrayed in Fig. 11 . Significant wave heights, $H$, and periods, $T$, are plotted against arrival times and envelope curves drawn in to embrace the plotted points and indicate the overall growth and decay of $\mathrm{H}$ and $\mathrm{T}$ with time.

The significant wave heights, such as obtained in Fig. 11, would be subject to considerable reduction upon the waves reaching the coastline, as a result of wave energy losses sustaned through friction and refraction over the continental shelf. These modifications were not allowed for in this study.

\section{BASIS FOR CORRELATING SAMPLE HEIGHTS WITH HURRICANE CHARACTERISTICS}

While the wave energy index, E, of Reid [1955], Eq.(1), is an adequate indication of the wave generating capacity of a stationary hurricane in a wide expanse of ocean, it fails to take into account the differing lengths of fetch in variable directions resulting from forward movement of the hurricane. In order to make use of the sample values of $\mathrm{H}$ and $\mathrm{T}$ derived from the detailed study of the nine selected hurricanes in any generalization of hurricane wave statistics it was necessary to correlate the wave heights and periods determined with some more satisfactory index of each storm's directional wave generating potential, with due regard to the storm's idiosyncrasies in crossing a given tract of water.

This problem may be approached by reverting to the fact, pointed out by Reid and Bretschneider [1953], by Re1d [1955] and again by Bretschneider [1956], that, for hurricane conditions, the dimensionless parameters $\frac{\mathrm{gH}}{\mathrm{U}^{2}}$ and $\frac{\mathrm{gF}}{\mathrm{U}^{2}}$ are statistically related by an equation which approximates to

$$
\frac{\mathrm{gH}}{\mathrm{U}^{2}}=0.0026\left(\frac{\mathrm{gF}}{\mathrm{U}^{2}}\right)^{\frac{1}{2}} \text {. }
$$

This implies that

$$
\mathrm{H} \propto \mathrm{U} \sqrt{\mathrm{F}} .
$$

It is possible to show from Eq. (6) that maximum wind velocity in a hurricane is proportional to $(\Delta p)^{1 / 2}$, whence from Eq.(12)

$$
H \propto \sqrt{(\Delta p) F} \text {. }
$$




\section{COASTAL ENGINEERING}

This result is the basis of Eq. (1) if the fetch is regarded as stationary and proportional to $\mathrm{R}$, the radius to maximum winds. However, the circumstance of the movement of a hurricane along some arbitrary path may be expected seriously to detract from the validity of Eq.(1) since F is then largely a function of that path.

To illustrate this, the application is shown in Fig. 12 of an HtFT forecasting diagram [W1lson, 1955] to the idealized windfield of a hurricane. A uniform (root mean square) wind velocity, $U_{r}$, is considered to prevail over an effective fetch, $a b$, of length $4 R$ repres enting a wind velocity profile through the hurricane. For such a uniform wind it is sufficient to consider only those forecasting curves $\mathrm{H}_{U}(\mathrm{~F}), \mathrm{T}_{U}\left(t_{d}\right)$ and $\mathrm{F}_{U}\left(t_{d}\right)$ which specify significant wave height, period and fetch, as functions of the indicated variables applicable at the constant wind velocity $U_{r}$.

The hurricane is assumed to be crossing coastline $A$ at a time when three-quarters of its effective fetch, aO, is over water. Along a particular dir ection line leading to coastline $B_{1}$, the storm is assumed to advance, in the first instance, at velocity $V_{1}$, resulting in the space-time wind-field shown stippled behind the line of advance ac. Waves originating as ripples at $O$ propagate along $O c$ until they leave the wind area at $\mathrm{C}$ with maximum height $H_{1}$, and period $T_{1}$, given by points $d$ and $e$.

In a direction along which the extent of ocean may be $\mathrm{AB}_{2}$, at right angles to the true line of advance of the storm, there can obviously be no forward advance of the wind system $\left(V_{2}=0\right)$, w1th the result that the wind-field in this case covers an area directly below ab in Fig. 12, behind the line af. In consequence the waves which start from $O$ now leave wind domination at $\mathrm{f}$ with maximum height $\mathrm{H}_{2}$ and period $\mathrm{T}_{2}$ corresponding to points $a$ and $g$.

Finally, in yet another direction, giving an extent of ocean $\mathrm{AB}_{3}$, the wind although blowing in the direction of $\mathrm{B}_{3}$, may be receding due to the recession of the storm at velocity $V_{3}$ along the line ah. Waves originating at $O$ and travelling along oh thus pass out of the wind at $h$ with maximum height $\mathrm{H}_{3}$ and period $\mathrm{T}_{3}$, as given by points $\mathrm{k}$ and 1 .

These several examples serve to show the importance of the actual fetch lengths $\mathrm{Od}, \mathrm{Oa}$, and $\mathrm{Ok}$ on the wave height and period - fetch lengths which depend on the movement of the storm and the particular direction being considered as well as upon the basic (stationary storm) fetch, somewhat arbitrarily taken as $4 \mathrm{R}$. In practice then, $F$ in Eq. (13) may be conside to be some function of $R$ and $\Delta F$ where $\Delta F$ corresponds to such increm of fetch as ad or ak in Fig.12.

In place of $\mathrm{E}$ of Eq.(1) as a criterion of the wave generating capacity a hurricane, the parameter $\sqrt{(\Delta \mathrm{p})(2 \mathrm{R}+\Delta \mathrm{F})}$ was therefore adopted for 


\section{HURRICANE WAVE STATISTICS FOR THE GULF OF MEXICO}

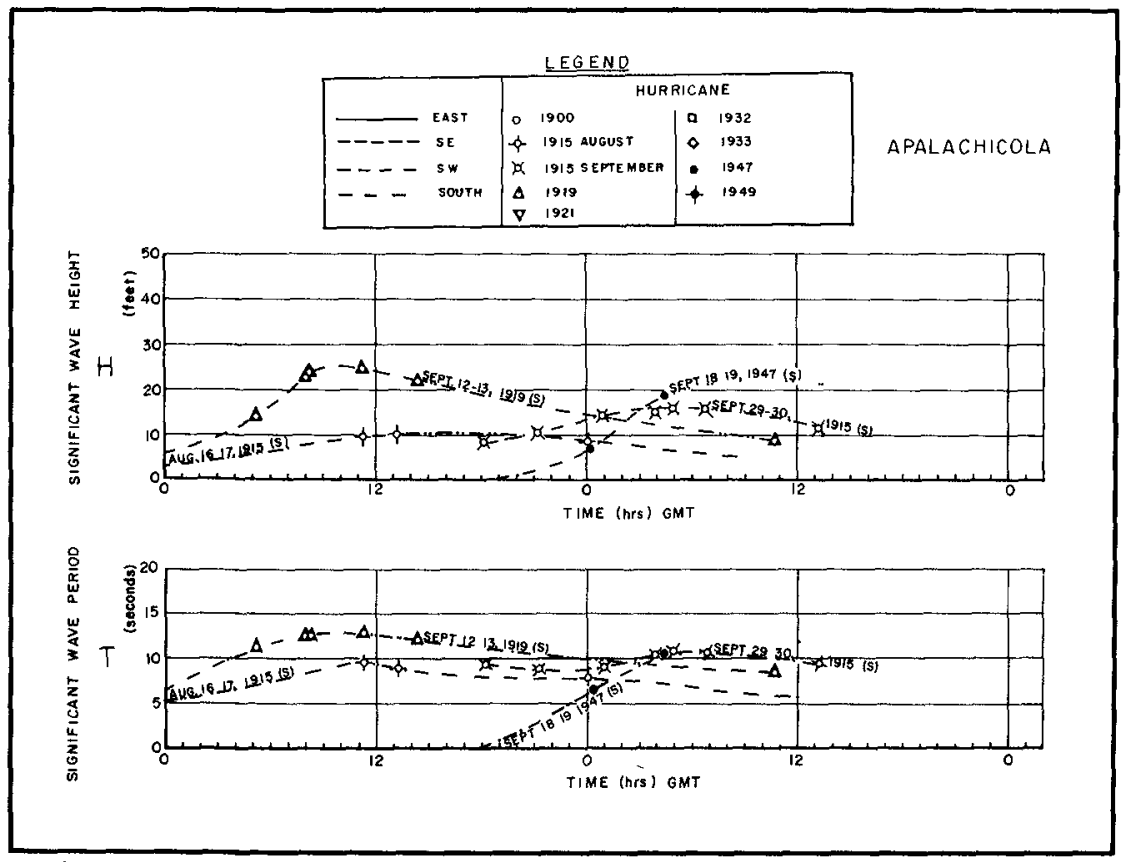

Fig. 11. Envelope Curves of liaximum Significant liave Hoight and Period as Functions of Arrival Time at Deep-later (100 Fathoms) Stations off Apalachicola.

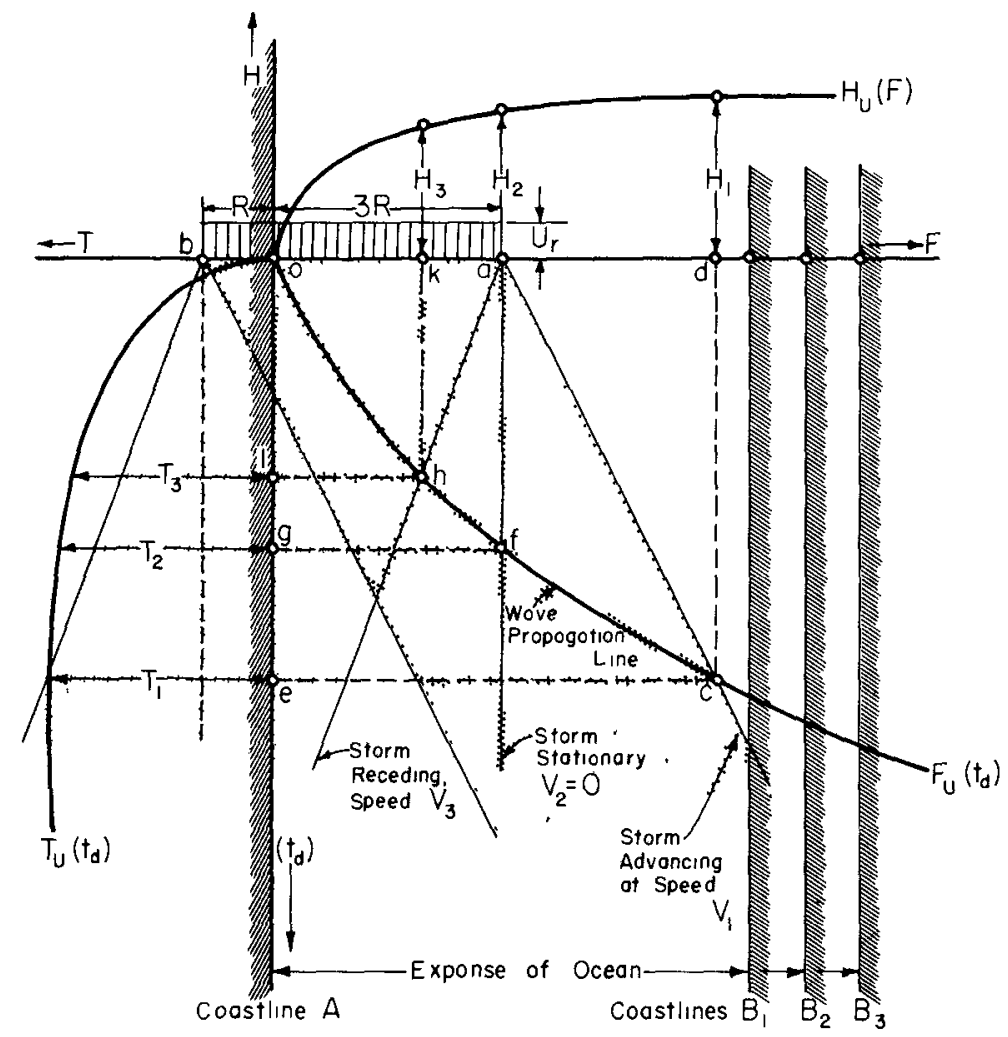

Fig. 12. Schenatic Diagrarn of Directional Effect on Hurricane Fetches or Wind Fields. 


\section{COASTAL ENGINEERING}

purposes of seeking a constant of proportionality in the statement of Eq.(13). The aim here was to make it possible for wave height $\mathrm{H}$ to be determined for additıonal storms (other than the selected nine), for which the characteristic: $(\Delta p)$ and $R$ were known. Since particulars of the fetches for these additiona storms, in the absence of detalled analysis, would have to be estimated, the basis of estimation that would have to be applied in deriving $\Delta \mathrm{F}$, was deter mined from experience with the nune hurricanes analyzed (for which the true fetches were known).

Values of $F(=2 R+\Delta F)$ assigned in this way were incorporated into the parameter $\sqrt{(\Delta p) F}$ and plotted against maximum significant wave heights, $H$, obtained from the envelope curves, such as Fig. 11. The expected linear relationship evolves in Fig. 13(a).

\section{BASIS FOR CORRELATING SAMPLE PERIODS WITH HURRICANE CHARACTERISTICS}

It has been shown [Wilson, 1955] that the statistical deep water relatic ship between the ratio of wave phase-velocity, $c$, to wind velocity, $U$, and th parameter $\frac{g F}{U^{2}}$ can be fitted satisfactorily by an equation of the form:

$$
\frac{c}{U}=1.40 \tanh \left\{\frac{4.36}{100}\left(\frac{\mathrm{gF}}{\mathrm{U}^{2}}\right)^{\frac{1}{3}}\right\} .
$$

For the same (hurricane) conditions prescribed in deducing Eq.(11), the vall of the hyperbollc tangent in Eq.(14) approximates to the angle, thereby simplifying the expression to

$$
\frac{c}{U} \propto \sqrt[3]{\frac{g F}{u^{2}}}
$$

Since $c \propto T$ for deep water conditions and $U_{\max } \propto \sqrt{\Delta p}$ the expressic (15) further resolves to

$$
\mathrm{T} \propto \sqrt[3]{\mathrm{F} \sqrt{\Delta \mathrm{p}}}
$$

Determination of the constant of proportionality in Eq.(16) provided the mea of finding $\mathrm{T}$ for all hurricanes not analysed whose characteristics $\mathrm{R}$ and ( $L$ were known. The best-fit regression line in Fig. 13(a) was used to advantą in determining more refined values of $F$ to be used opposite values of $H$ anc their corresponding values of maximum $T$, as found from the envelope cur (such as Fig. 11). In this way the parameters $\sqrt[3]{F \sqrt{\Delta p}}$ were compute and plotted against $\mathrm{T}$ for the nune selected hurricanes. Again a satısfact regression line was obtained and the underlying principles confirmed. 


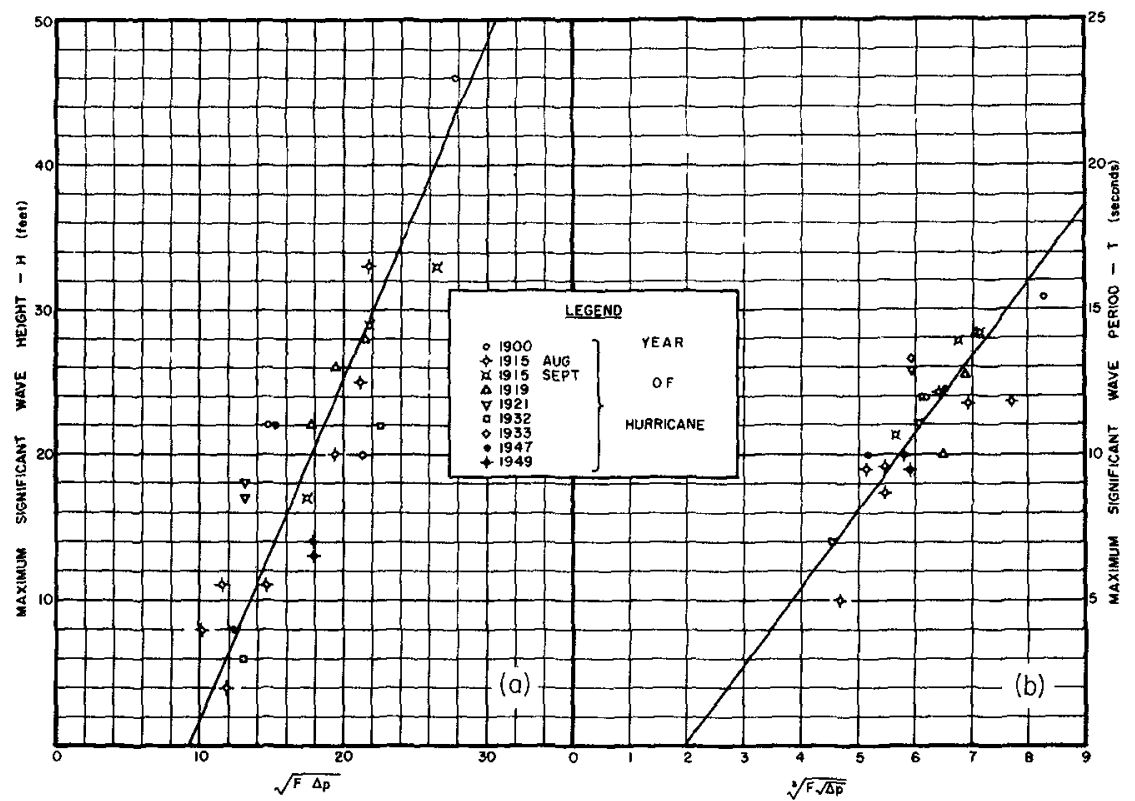

Fig. 13. Correletion of Hindcast Wave Heights and Periods with Parameters Involving Hurricane Characteristics and Movements.
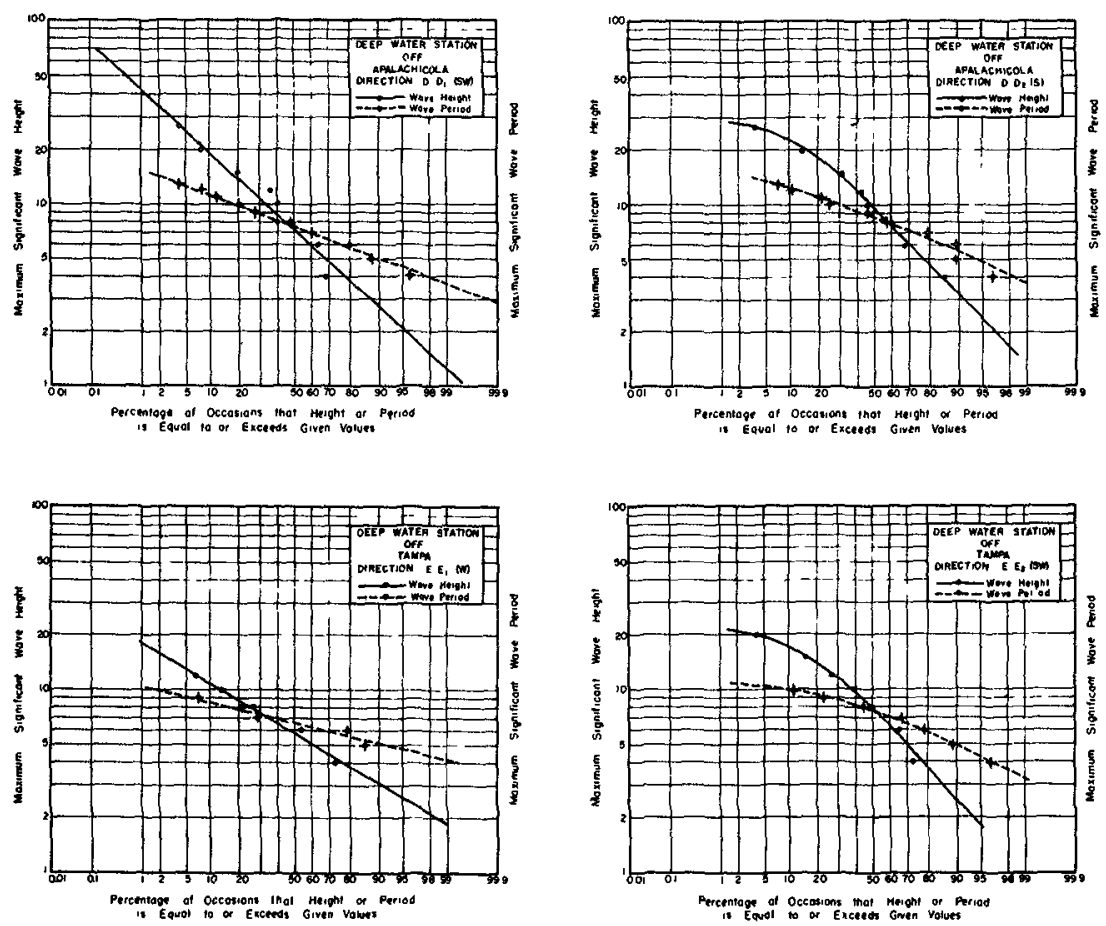

Fig. 14. Percentage of Occesions that Hurricane Significant Wave Heights and Periods Equal or Bxceed a Given Value along Directions: $\mathrm{DD}_{1}, \mathrm{DD}_{2}$ (Apalochicola); $\mathrm{EE}_{1}, \mathrm{EE}_{2}$ (Tampa). Height in feet; period in seconds. 


\section{EXTENDING THE SAMPLE OF SIGNIFICANT WAVE HEIGHTS AND PERIOC}

From the regression lines of Figs. 13 it was possible without further detailed hindcasts of hurricane waves to increase the sample 'population' of wave heights and periods in the eleven durections bearing on the five stations $A$ to $E$ The mechanism for doing this was simply to estimate the applicable fetches $F$ in the various directions for an additional 23 hurricanes whose characteristics $\mathrm{R}$ and $\Delta \mathrm{p}$ were known. The values of $\mathrm{F}$ were judged on the same basis as had been done for the selected hurricanes with due regard to the tracks follower by the storms in relation to the eleven directions to the shore stations. The charts of hurricane tracks in the Gulf of Mexico from 1901 to 1943, given by Tannehill [1944], were found invaluable for this purpose.

The judgement of $\mathrm{F}$ was necessarily subjective; for this reason the estimations were made only by one person (the author) on the strength of experier gained in handling the windfields in the worked cases. It may at least be said th the estimated values of $\mathrm{F}$ for the 23 storms cited were derived in comparable fashion to the values of $\mathrm{F}$ adopted for the 9 selected storms. It is a fair conclusion also, since the parameters $\sqrt{\mathrm{F} \Delta \mathrm{p}}$ and $\sqrt[3]{\mathrm{F} \sqrt{\Delta_{\mathrm{p}}}}$ for the 9 hurricanes comply with the theoretico-empirical trends in relation to $H$ and $T$ respectively, that the same trends will be obeyed by these parameters as founc for the 23 additional storms.

The resultant statistics were plotted as the percentage of occasions that hurricane waves equalled or exceeded stated helghts or periods at the deep water limit along the various approach directions to the shore stations. Fig.1، is a sample of these plots for Apalachicola and Tampa. In quite a number of cases the points, plotted on log probability paper, conformed well to straight line (normal) distributions. Best-fit regression lines, drawn through the plotte points, may be considered to have improved still further the adequacy of the sample 'populations' upon which the further statistics are based. Data equivalent to the above have been tabulated in Tables AI and AII (Appendix A).

\section{FREQUENCY OF OCCURRENCE OF HURRICANE WAVES OF GIVEN SIGNIFICANT HEIGHT OR PERIOD}

As remarked earlier, Tannehlll [1944] has recorded and charted the tracks of some 112 tropical storms which entered the Gulf of Mexico between 1900 and 1943. Exclusive of the 9 selected, and 23 additional, full hurricanes already considered, the balance of these storms were examined for their capacity to generate waves in the several approach directions to the shore stations $\mathrm{A}$ to $\mathrm{E}$, taking into consideration the tracks followed. It was possibl to determine when shoreward generation of waves in the various directions could, or could not, have taken place. 
HURRICANE WAVE STATISTICS FOR THE GULF OF MEXICO

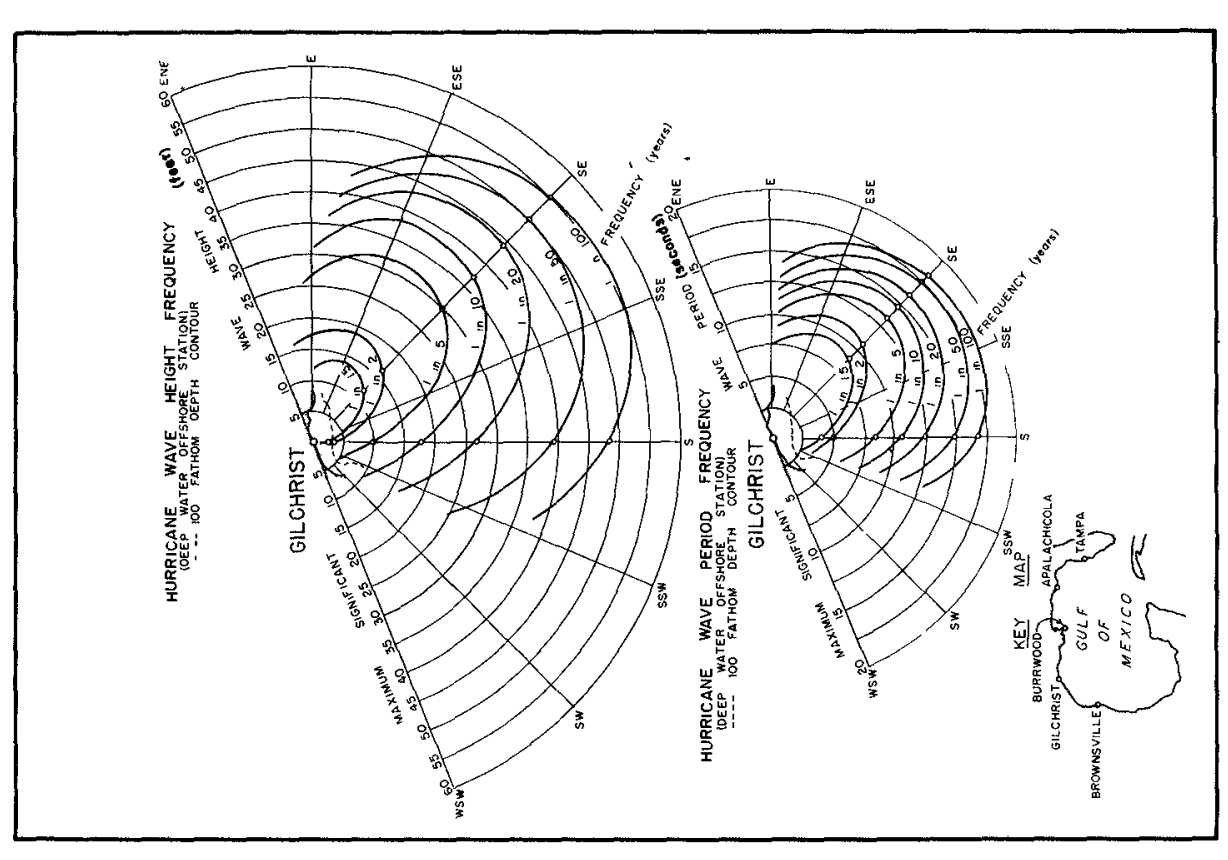

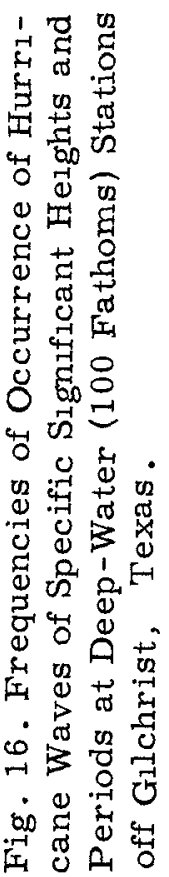

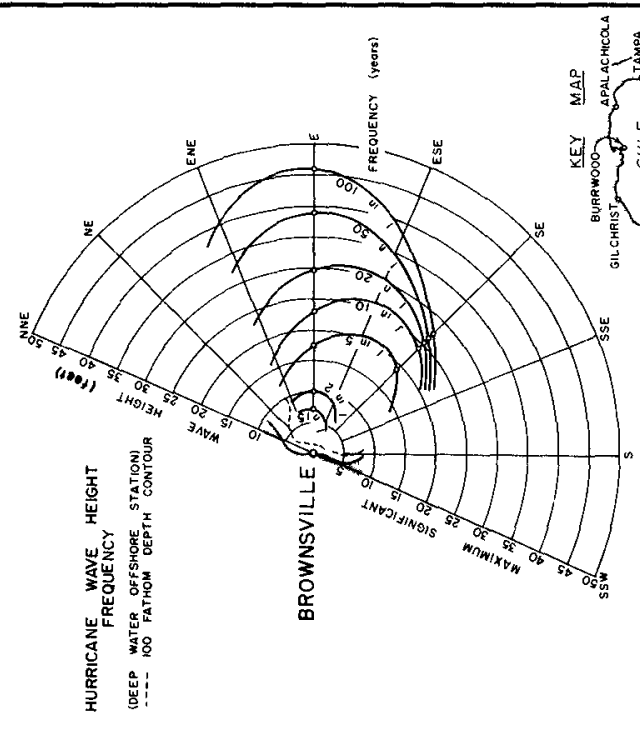

$\stackrel{50}{4}$

$\stackrel{\square}{\square}$

出苨 द्व

元

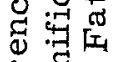

\&

$00=$

$\bigcirc: H$

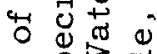

요욜

벙 क्ष

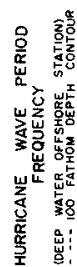

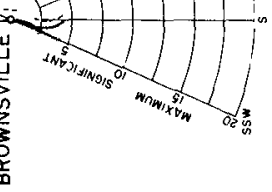

凹్

ป

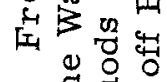

10 过

$\rightarrow \int_{-1}^{\infty} \Omega_{1}$

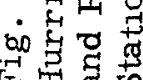




\section{COASTAL ENGINEERING}

From this it was possible to add up the total number of incidences, N, that tropical storm waves had been experienced from a given direction for all 112 storms referred to. However, of these 112 storms only 66 have been rated as worthy of being retained in the category of hurricanes so that $66 / 112$ of the number of incidences, $N$, of tropical storm waves in 44 years in any of the chosen directions will represent the frequency of occurrence of hurricane waves in this length of time.

Denoting 1 in $\mathrm{n}$ years as the equivalent of this frequency, then

$$
\mathrm{n}=\frac{44}{\frac{66}{112} \mathrm{~N}} \text { or } \quad \frac{74.6}{\mathrm{~N}} \text { years } .
$$

(Values of $\mathrm{N}$ and $\mathrm{n}$ are given in Table AI, Appendix A). Further, if $\mathrm{f}$ be the percentage of hurricane wave occasions for which $H$ (or $T$ ) equals or exceed: a certain value (such as specified by the regression lines in Fig. 14), then it may be expected that hurricane waves of this height (or period) will be experienced once in $\frac{100 \mathrm{n}}{\mathrm{f}}$ years. If this be written as once in $\mathrm{m}$ years, whe m has successive values $1,1.5,2,5,10,20,50,100$ years, then

$$
\mathrm{f}=\frac{100 \mathrm{n}}{\mathrm{m}} \% \text {. }
$$

Tabulation of values of $f$ is given in Tables A III (Appendix A).

The final step in the compilation of hurricane wave statistics involved interpreting values of $f$ in terms of the corresponding significant wave height $H$ (or periods $T$ ) by reading from the regression lines such as Fig. 14. Table A IV and AV (Appendix A) list the applicable values of $H$ and $T$ respectivel

To condense the results into easily comprehensible form, polar diagras of the frequency ( 1 in $\mathrm{m}$ years) of hurricane (significant) wave heights and periods are presented in Figs. 15 to 19. These are based directly on the dat: of Tables A IV and AV. To take Fig. 17 as an example, the two polar diagr therein give isolines of the frequency ( 1 in $\mathrm{m}$ years, where $\mathrm{m}$ is successive $1,1.5,2,5,10,20,50$, and 100 years), upon polar co-ordinates of which concentric semi-circles (or radius values) represent magnitudes of significa wave height (or perıod) and radial lines (or bearings) represent approach directions toward the shore station at Burrwood, Miss. The contours of frequency have been interpolated from the plotted points for directions $\mathrm{CC}_{1}, \mathrm{CC}$ and $\mathrm{CC}_{3}$ so as to cover all directions from which waves of any consequence might be expected.

It may be inferred from the frequency curves of significant wave heigh for Burrwood (Fig. 17), to continue the example, that the chances of getting $35 \mathrm{ft}$. high deep-water significant waves from the south is 1 in 100 years. 
HURRICANE WAVE STATISTICS FOR THE GULF OF MEXICO
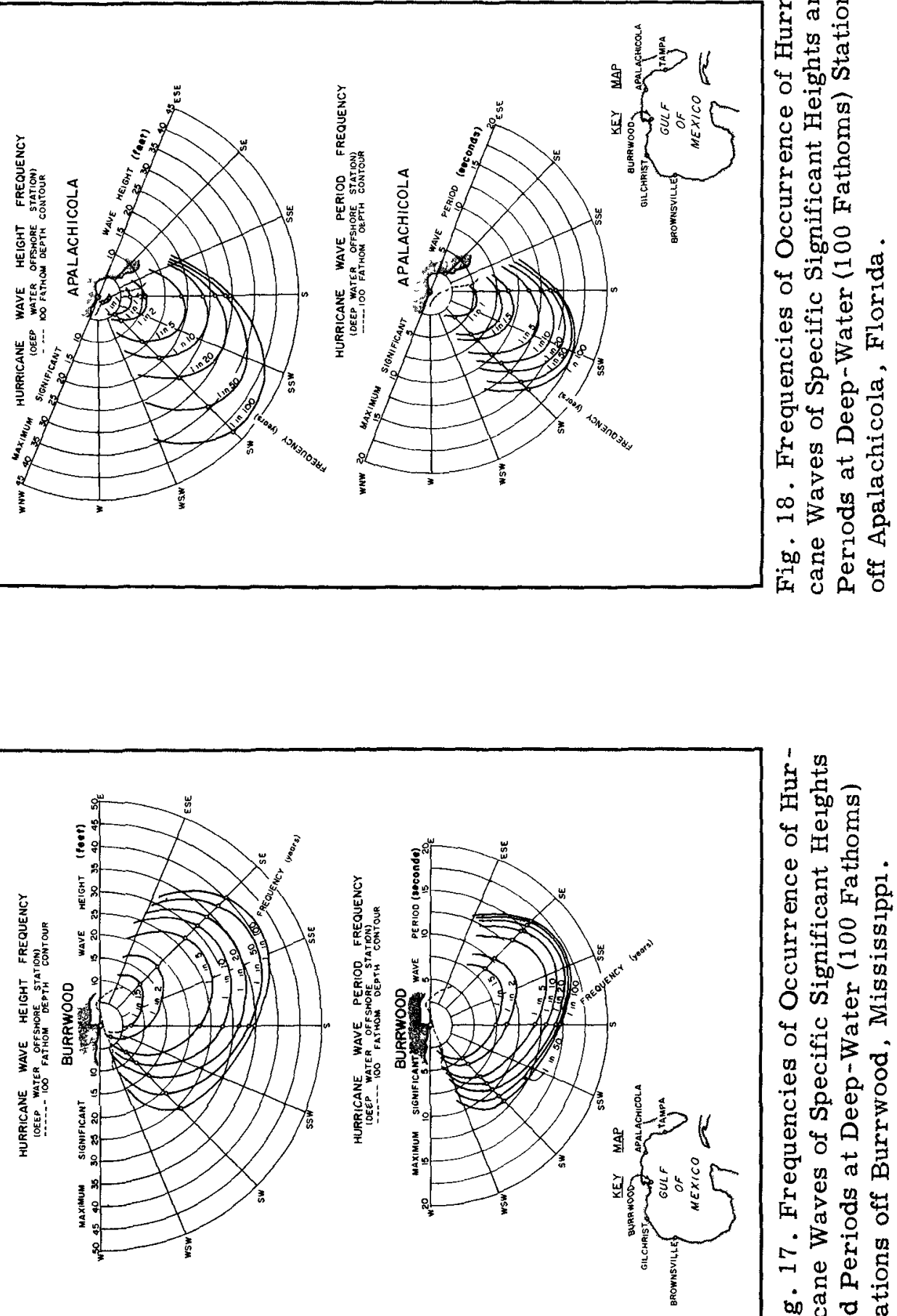

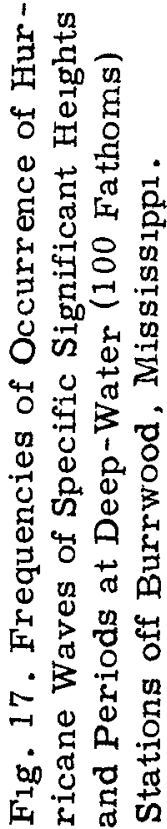




\section{COASTAL ENGINEERING}

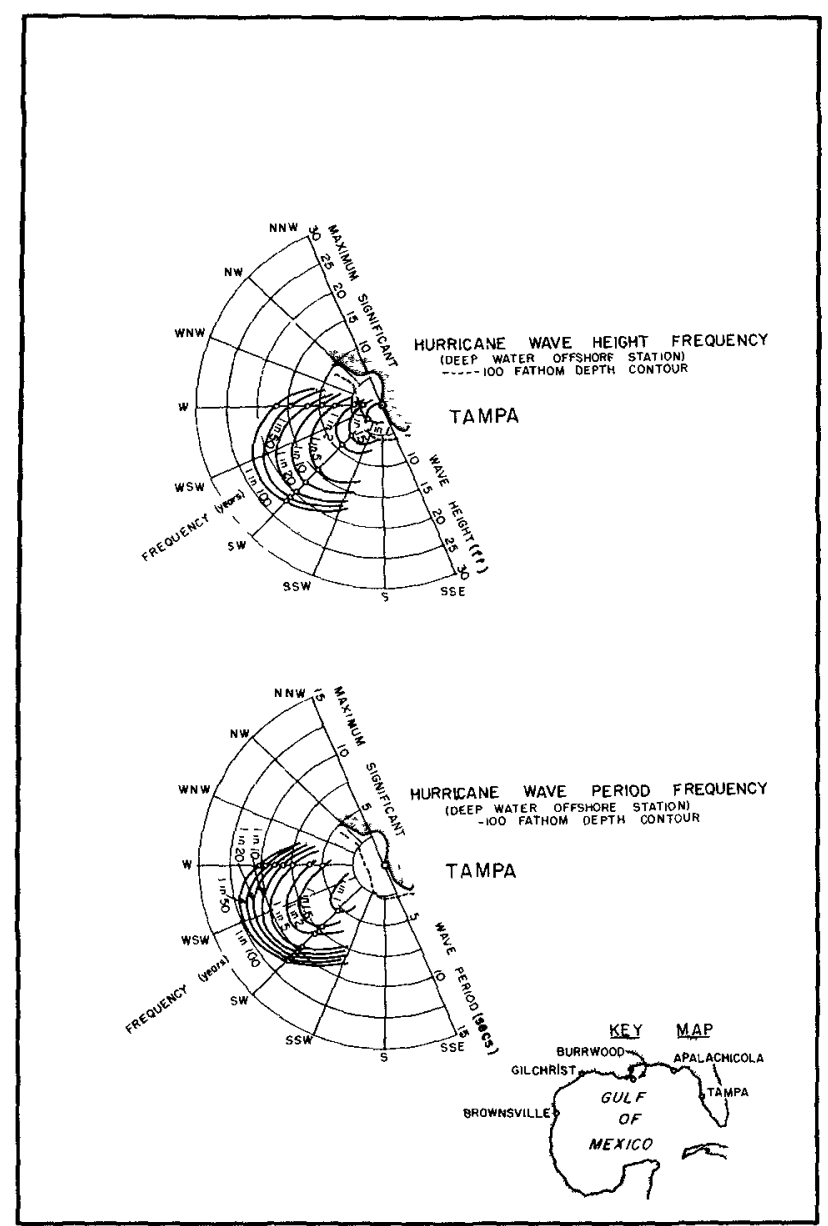

Fig. 19. Frequencies of Occurrence of Hurricane Waves of Specıfic Signıficant Heights and Periods at DeepWater (100 Fathoms) Stations off Tampa, Florida.

From SSE, however, the chances are 1 in 20 years. The highest waves of all are likely to come from a direction between SE and SSE and may be as much as 42 feet once in 100 years or as high as 28 feet once in 5 years. Onci in 2 years waves as high as 18.5 feet may be expected from the south-east. The significant wave periods corresponding to these latter heights would be 17 secs once in 100 years or 14 secs once in 5 years from the direction between SE and SSE; 10.4 secs once in 2 years from the SE.

It should be noted that the quoted frequencies refer strictly to waves generated in the Gulf by full hurricanes and do not preclude the possibility of existence of waves of comparable magnitudes generated by frontal storm systems which do not classify as hurricanes or tropical storms. 


\section{CONCLUSIONS}

Comparing the polar frequency diagrams for the five stations (Figs. 15 to 19) 1t is found that Gilchrist (Galveston area) has the expectation of highest hurricane waves. At frequencies of once in 2 years and oftener, however, wave heights are as great at Burrwood as at Gilchrist and, therefore, along the intermediate coastline. Waves of considerable height may be expected from the SE near Gilchrist and from the SSE to SE near Burrwood at somewhat rare intervals. Once in 5 years significant wave heights in these deep water areas will reach about 30 feet; once in 2 years about 19 feet.

The comparative vulnerability of the five (deep-water) stations to hurricane waves may be listed in the following order :
1. Gilchrist, Texas
2. Burrwood, Mississippi
3. Brownsville, Texas
4. Apalachicola, Florida
5. Tampa, Florida

Brownsville and Apalachicola, in the above, actually have about equal susceptibilities. Tampa, it can readily be seen, is well protected from hurricane wave attack by virtue of its position in the Gulf in relation to the tracks usually followed by hurricanes.

\section{ACKNOWLEDGEMENT}

Submission of this paper, which is a shortened and refined version of Technical Memorandum No. 98, recently published by the Beach Erosion Board, Corps of Engineers, U.S. Army, 1s made possible through the courtesy of that body. The assistance of Codie S. Wells in the work of hindcasting the hurr1cane waves is gratefully acknowledged.

\section{REFERENCES}

1. Beach Erosion Board (1955); Shore Protection Planning and Design, Tech. Report No. 4, Beach Erosion Board, Corps of Engineers, U.S. Army, Washington, D.C.

2. Bretschneider, C.L. (1956); Hurricane Design Wave Practices, Proc. A.S. C.E. (Journ. Waterways and Harbors Div.), v. 83 (ww 2), May 1957.

3. Cline, I.M. (1926); Tropical Cyclones, New York, 301 pp.

4. Haurwitz, B. (1941); Dynamıc Meteorology, New York. 


\section{COASTAL ENGINEERING}

5. Holmboe, J. (1945); Dynamic Meteorology, New York, 378 pp.

6. Myers, V.A. (1954); Characterıstics of United States Hurricanes Pertinent to Levee Design for Lake Okeechobee, Florida, Hydrometeorological Report No. 32, Weather Bureau, U.S. Dept. of Commerce, Washington, D. C., March 1954, 106 pp.

7. Re1d, R.O. and Bretschneider, C. L. (1953); Surface Waves and Offshore Structures, Tech. Report No. 38-0, Texas A.\& M. Research Foundation, October, 1953, $33 \mathrm{pp}$. and 11 plates ( unpublished).

8. Reid, R.O. (1955); On the Classıfication of Hurricanes by Storm Tide and Wave Energy Indices, Paper presented at May 1955 Meeting Am. Geophys. Union and Am. Met. Soc. (Publication pending as A.M.S. Meteorological Monograph No. 10).

9. Tannehill, 1. R. (1944); Hurricanes, Princeton, 269 pp.

10. Wilson, B.W. (1954); Graphical Approach to the Forecasting of Waves in Moving Fetches, Tech. Memo No. 73, Beach Erosion Board, Corps of Engineers, U.S. Army, Washington, D.C., April 1955, $31 \mathrm{pp}$.

\section{APPENDIX A}

TABL.E A 1

PERCENT OF OCGASIONS THAT HURRICANE WAVE HEIGHTS EQUAL OR EXCEED GIVEN VALUES IN VARIOUS DIRECTIONS

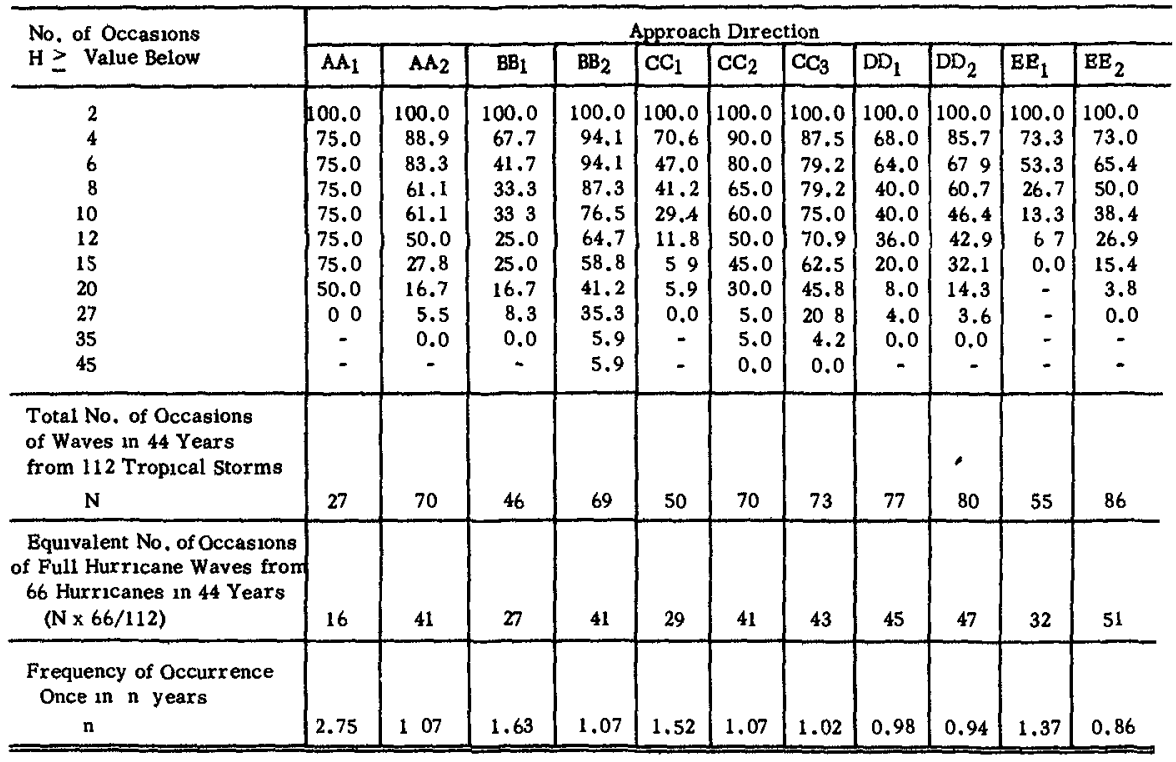




\section{HURRICANE WAVE STATISTICS FOR THE GULF OF MEXICO}

TABLE AII

PERCENT OF OCCASIONS THAT HURRICANE WAVB PBRIODS EQUAL OR EXCEBD GIVBN VALUES IN VARIOUS DIRECTIONS

\begin{tabular}{|c|c|c|c|c|c|c|c|c|c|c|c|}
\hline \multirow{2}{*}{$\begin{array}{l}\text { No. of Occasions } \\
T \geq \text { Value Below }\end{array}$} & \multicolumn{11}{|c|}{ Approach Directlon } \\
\hline & $\mathrm{AA}_{1}$ & $\mathrm{AA}_{2}$ & $\mathrm{BB}_{1}$ & $\mathrm{BB}_{2}$ & $\mathrm{CC}_{1}$ & $\mathrm{CC}_{2}$ & $\mathrm{CC}_{3}$ & $\mathrm{DD}_{1}$ & $\mathrm{DD}_{2}$ & $\mathrm{BE}_{1}$ & $\mathbf{E E}_{2}$ \\
\hline 4 & 100.0 & 100.0 & 100.0 & 100.0 & 100.0 & 100.0 & 100.0 & 96.0 & 96.4 & 100.0 & 96.3 \\
\hline 5 & 100.0 & 100.0 & 100.0 & 100.0 & 94.0 & 95.0 & 95.8 & 88.0 & 89.3 & 85.7 & 88.9 \\
\hline 6 & 75.0 & 94.5 & 66.7 & 93.7 & 82.5 & 90.0 & 91.7 & 80.0 & 89.3 & 78.0 & 77.8 \\
\hline 7 & 75.0 & 61.1 & 50.0 & 87.5 & 47.0 & 75.0 & 83.4 & 60.0 & 78.5 & 28.6 & 66.8 \\
\hline 8 & 75.0 & 61.1 & 33.3 & 81.3 & 23.5 & 55.0 & 79.2 & 48.0 & 57.2 & 21.4 & 44.4 \\
\hline 9 & 75.0 & 50.0 & 25.0 & 68.7 & 23.5 & 50.0 & 75.0 & 28.0 & 46.4 & 7.1 & 22.2 \\
\hline 10 & 75.0 & 38.9 & 25.0 & 68.7 & 0.0 & 40.0 & 66.7 & 20.0 & 25.0 & 0.0 & 11.1 \\
\hline 11 & 75.0 & 33.3 & 8.3 & 50.0 & - & 35.0 & 50.0 & 12.0 & 21.4 & - & 0.0 \\
\hline 12 & 50.0 & 11.1 & 8.3 & 25.0 & - & 25.0 & 29.2 & 8.0 & 10.7 & - & - \\
\hline 13 & 0.0 & 5.5 & 8.3 & 25.0 & - & 5.0 & 12.5 & 4.0 & 7.1 & - & - \\
\hline 14 & - & 5.5 & 8.3 & 18.7 & - & 0.0 & 8.3 & 0.0 & 0.0 & - & - \\
\hline 15 & - & 5.5 & 0.0 & 6.3 & - & - & 8.3 & - & - & - & - \\
\hline 16 & - & 0.0 & - & 6.3 & - & - & 4.2 & - & - & - & - \\
\hline 17 & - & - & - & 0.0 & - & - & 0.0 & - & - & - & - \\
\hline
\end{tabular}

TABLE AIII

PERCENTAGE FREQUENCIES OF OCCURRENCE (f) OF HURRICANE WAVES IN VARIOUS DIRBCTIONS OF HEIGHT (OR PERIOD) GREATER THAN OR EQUAL TO A GIVEN VALUE

\begin{tabular}{|c|c|c|c|c|c|c|c|c|c|c|c|}
\hline \multirow{2}{*}{$\begin{array}{c}\text { Occurrences of Full } \\
\text { Hurricane Waves } \\
1 \text { in m Years }\end{array}$} & \multicolumn{11}{|c|}{ Approach Direction } \\
\hline & $\mathrm{AA}_{1}$ & $\mathrm{AA}_{2}$ & $\mathrm{BB}_{1}$ & $\mathrm{BB}_{2}$ & $\mathrm{CC}_{1}$ & $\mathrm{CC}_{2}$ & $\mathrm{CC}_{3}$ & $\mathrm{DD}_{1}$ & $\mathrm{DD}_{2}$ & $\mathrm{BE}_{1}$ & $\mathrm{BE}_{2}$ \\
\hline 1 & 275.0 & 107.0 & 163.0 & 107.0 & 152.0 & 107.0 & 102.0 & 98.0 & 94.0 & 137.0 & 86.0 \\
\hline 1.5 & 183.0 & 71.0 & 92.0 & 71.0 & 101.0 & 71.0 & 68.0 & 65.0 & 63.0 & 91.0 & 57.0 \\
\hline 2 & 138.0 & 53.0 & 81.0 & 53.0 & 76.0 & 53.0 & 51.0 & 49.0 & 47.0 & 68.0 & 43.0 \\
\hline 5 & 55.0 & 21.0 & 33.0 & 21.0 & 30.0 & 21.0 & 20.0 & 20.0 & 19.0 & 27.0 & 17.0 \\
\hline 10 & 27.5 & 11.0 & 16.0 & 11.0 & 15.0 & 11.0 & 10.0 & 10.0 & 9.0 & 14.0 & 9.0 \\
\hline 20 & 13.8 & 5.3 & 8.1 & 5.3 & 7.6 & 5.3 & 5.1 & 4.9 & 4.7 & 6.8 & 4.3 \\
\hline 50 & 5.5 & 2.1 & 3.3 & 2.1 & 3.0 & 2.1 & 2.0 & 2.0 & 1.9 & 2.7 & 1.7 \\
\hline 100 & 2.8 & 1.1 & 1.6 & 1.1 & 1.5 & 1.1 & 1.0 & 1.0 & 0.9 & 1.4 & 0.9 \\
\hline
\end{tabular}

TABLE AIV

SIGNIFICANT WAVE HEIGHTS OF HURRICANE WAVES IN VARIOUS DIRECTIONS CORRESPONDING TO FREQUENCIES (f) OF TABLE A III

\begin{tabular}{|c|c|c|c|c|c|c|c|c|c|c|c|}
\hline \multirow{2}{*}{$\begin{array}{c}\text { Occurrences of Full } \\
\text { Hurricane Waves } \\
1 \text { an m Years }\end{array}$} & \multicolumn{11}{|c|}{ Approach Direction } \\
\hline & $\mathrm{AA}_{1}$ & $\mathrm{AA}_{2}$ & $\mathrm{BB}_{1}$ & $\mathrm{BB}_{2}$ & $\mathrm{CC}_{1}$ & $\mathrm{CC}_{2}$ & $\mathrm{CC}_{3}$ & $\mathrm{DD}_{1}$ & $\mathrm{DD}_{2}$ & $\mathbf{E E}_{1}$ & $\mathbf{E E}_{2}$ \\
\hline 1 & - & - & - & - & $=$ & - & - & 1.5 & 2.6 & - & 3.0 \\
\hline 1.5 & - & 7.1 & 1.3 & 11.5 & - & 7.5 & 12.8 & 5.3 & 7.2 & 3.0 & 6.8 \\
\hline 2 & - & 9.8 & 2.3 & 16.0 & 3.6 & 11.4 & 18.4 & 7.3 & 10,4 & 4.6 & 9.0 \\
\hline 5 & 19 & 17.5 & 9.6 & 30.0 & 8.4 & 23.0 & 27.5 & 13.8 & 18.7 & 7.7 & 14.8 \\
\hline 10 & 24 & 23.0 & 17.5 & 37.0 & 12,0 & 28.3 & 31.2 & 19.2 & 23.5 & 9.8 & 17.5 \\
\hline 20 & 25.5 & 29.6 & 26.5 & 44.0 & 15.8 & 32.0 & 34.0 & 25.5 & 26.2 & 12.0 & 19.7 \\
\hline 50 & 26.4 & 39.0 & 39.0 & 50.0 & 21.5 & 34.0 & 37.7 & 34.6 & 28.5 & 14.8 & 21.2 \\
\hline 100 & 27.5 & 46.0 & 48.0 & 55.0 & 26.0 & 35.0 & 40.0 & 42.5 & 29.5 & 17.0 & 21.6 \\
\hline
\end{tabular}

TABLE AV

SIGNIFICANT WAVB PERIODS OF HURRICANE WAVES IN VARIOUS DIRECTIONS CORRESPONDING TO FREQUENCIES (f) OF TABLE A III

\begin{tabular}{r|r|r|r|r|r|r|r|r|r|r|r}
\hline 1 & - & - & - & - & - & - & - & 3.9 & 5.0 & - & 5.4 \\
1.5 & - & 7.6 & 4.0 & 9.0 & - & 7.4 & 8.8 & 6.6 & 7.7 & 5.0 & 7.2 \\
2 & - & 8.7 & 5.0 & 10.5 & 6.1 & 8.7 & 10.3 & 7.5 & 8.8 & 6.0 & 8.0 \\
5 & 11.3 & 11.1 & 8.4 & 13.4 & 8.0 & 11.8 & 13.2 & 9.8 & 11.2 & 7.4 & 9.6 \\
10 & 14.3 & 12.6 & 10.6 & 14.7 & 9.0 & 13.1 & 14.6 & 11.2 & 12.6 & 8.2 & 10.1 \\
20 & 15.3 & 14.0 & 12.5 & 16.0 & 9.9 & 14.2 & 15.4 & 12.6 & 13.6 & 8.8 & 10.5 \\
50 & 15.8 & 15.7 & 14.9 & 17.4 & 11.0 & 14.6 & 16.0 & 14.3 & 14.2 & 9.6 & 10.8 \\
100 & 16.0 & 16.9 & 16.8 & 18.2 & 11.8 & 14.7 & 16.1 & 15.4 & 14.3 & 10.2 & 11.0 \\
\hline
\end{tabular}

